\title{
LA IGUALDAD EN LA REGULACIÓN CONSTITUCIONAL DE LA FAMILIA, EL MATRIMONIO Y LOS MENORES
}

\author{
Nicolás Pérez Sola
}

\begin{abstract}
SUMARIO: 1 . El SIGNIFICADO CONSTITUCIONAL DE LAS NOCIONES DE FAMILIA Y MATRIMONIO. LA CONSTITUCIONALIDAD DEL MATRIMONIO HOMOSEXUAL Y SU ENCAJE EN NUESTRO ORDENAMIENTO SOBRE EL DERECHO DE FAMILIA. 1.1. Cuestiones de capacidad. 1.2. La intervención del Encargado del Registro Civil y el alcance del control sobre los contrayentes en los supuestos de matrimonio de complacencia. 1.3. Concepto constitucional del matrimonio. 1.4. Las Uniones de Hecho. 1.4.1. La igualdad ante la ley. 1.4.2. Posibles efectos en caso de crisis. 2. LA ADOPCIÓN LLEVADA A CABO POR LAS PAREJAS HOMOSEXUALES A LA LUZ DE LA STC 198/2012. 3. AlguNOS PROBLEMAS ESPECÍFICOS RELATIVOS A LA INVESTIGACIÓN DE LA PATERNIDAD. 3.1. La revelación de la identidad del donante a efectos de la determinación legal de la filiación: un tratamiento normativo diferenciado susceptible de conculcar el principio de igualdad ante la Ley. 3.2. La impugnación de la paternidad (art. 136.1 CC) y la regulación de la legitimación del progenitor biológico para reclamar la filiación no matrimonial, cuando falta la posesión de estado (art. 133 CC). 4. LA INTROMISIÓN DEL LEGISLADOR EN ASUNTOS PERSONALÍSIMOS CONCERNIENTES AL MENOR. 4.1. La interrupción voluntaria del embarazo de la menor de 16 y 17 años. 4.2. La atribución de la facultad de decidir sobre la educación a recibir por el menor.
\end{abstract}

1. EL SIGNIFICADO CONSTITUCIONAL DE LAS NOCIONES DE FAMILIA Y MATRIMONIO. LA CONSTITUCIONALIDAD DEL MATRIMONIO HOMOSEXUAL Y SU ENCAJE EN NUESTRO ORDENAMIENTO SOBRE EL DERECHO DE FAMILIA

El punto de partida no es otro que el examen de la regulación constitucional, así como su interpretación y efectos desde la perspectiva de la jurispruden- 
cia constitucional, en relación con aquellas cuestiones básicas del derecho de familia que han sido objeto de regulación en la norma fundamental del Estado: las nociones constitucionales de matrimonio (art. 32, CE) y familia (art. 39), y las consecuencias jurídicas que se derivan de ellas. En primer término para reconocer, bajo el prisma del principio de igualdad y la prohibición de discriminación (arts. 9.2 y 14, CE), las consecuencias que tiene esa recepción, tanto respecto del significado en sí mismo del concepto (matrimonio) como de las relaciones internas (entre cónyuges); así como los efectos jurídicos comparativos con otras modalidades de unión conyugal o familiar. En segundo lugar, es necesario examinar el contenido y alcance que para el TC deriva de los mandatos que encomiendan a los poderes públicos la protección de la unidad familiar y en general, y especialmente de una parte de sus miembros (menores).

El marco constitucional en el que tiene su encuadre el matrimonio así como otras formas de familia, impone necesariamente la igualdad entre las personas que las configuran, con una protección especial al superior interés del menor, pero dejando al legislador un amplio margen para la regulación específica del matrimonio como, en su caso, de otras formas de convivencia. Por tanto, compete al legislador la regulación del matrimonio como de otras formas de familia no matrimonial, como las uniones de hecho, y sus posibles efectos jurídicos.

El artículo 32 de la CE contiene un enunciado bastante explícito a priori, en el que se reconoce un derecho constitucional al que, sin embargo, no se le puede otorgar la categoría de «fundamental», ya que carece de posibilidades de ser invocado en un amparo constitucional o un amparo judicial preferente y sumario.

El objeto de ese derecho no resulta en principio controvertido, tanto en lo referido a sus titulares como respecto de su significado básico: el matrimonio del hombre y de la mujer, junto a la «plena igualdad jurídica» de los miembros que componen esta institución jurídica. Así pues, nada se especifica de partida sobre una posible fórmula alternativa de matrimonio formada por personas del mismo sexo.

La intención del constituyente se centró más bien en enfatizar -como finalidad primordial- la necesidad de asegurar el equilibrio, desde un punto de vista jurídico, entre los cónyuges que lo componen; sin que en aquel momento se plantease reflexión alguna en orden a determinar la necesidad de garantizar la naturaleza heterosexual de aquéllos.

Por tanto, dentro del marco constitucional, el legislador que dispone de un amplio margen ha llevado a cabo la regulación en el Código Civil de los derechos y obligaciones de los cónyuges, los supuestos de ruptura del matrimonio así como las relaciones paterno-filiales. Con posterioridad se ha avanzado la regulación matrimonial entre parejas homosexuales, si bien la actual regulación no acota otras posibles reformas ulteriores con consecuencias para las relaciones familiares y sus miembros. 
Para configurar el matrimonio, el Código Civil contiene prohibiciones expresas para contraerlo, y, en su caso, dispensas en algunos supuestos. Además, el consentimiento -elemento esencial en el matrimonio-, puede ser otorgado en supuestos equívocos frente a la exigencia de libertad en su otorgamiento. Es por ello que puede ser relevante plantear algunas cuestiones relativas a la capacidad para contraer el matrimonio.

\subsection{Cuestiones de capacidad}

Por cuanto se refiere a la regulación inicial del matrimonio en el Código Civil, hemos de recordar que el legislador expresamente ha previsto la imposibilidad de contraer matrimonio a los menores de edad no emancipados, los que estén ligados con vínculo matrimonial (art. $46 \mathrm{CC}$ ), así como quienes resulten afectados por las previsiones de parentesco determinadas en el art. 47.1 y 2 CC, al igual que «los condenados como autores o cómplices de la muerte dolosa del cónyuge de cualquiera de ellos» (art. 47.3 CC). Pudiera dudarse de la oportunidad de los límites marcados por el legislador en los dos primeros apartados de este último precepto ${ }^{1}$. Ahora bien, al objeto de realizar un contraste de constitucionalidad sobre el tercer supuesto de esta norma, podemos encontrarnos ante una previsión que tendría difícil acomodo constitucional, ya que se hace depender la imposibilidad de ejercer el derecho de contraer matrimonio a la preexistencia de una condena como «autores o cómplices de la muerte dolosa del cónyuge». La incorporación como límite al ejercicio del derecho de una condena previa por muerte dolosa del cónyuge podría constituir una previsión inconstitucional, en la medida en que genera una discriminación que puede entrar en colisión con el «contenido esencial» de ese derecho constitucional (art. 53.1, CE), además de que no obedece, o al menos resulta bastante discutible desde el punto de vista de la aplicación de un test de proporcionalidad sobre la limitación al ejercicio del derecho a contraer matrimonio, resultante del bien jurídico que se pretende proteger con dicha prohibición.

Por otra parte, el conjunto de prohibiciones relativas al derecho a contraer matrimonio son a continuación objeto de excepciones, cuando menos discutibles, de modo diverso a tenor de lo preceptuado en el artículo 48 CC. En primer lugar, puede no ser apropiado otorgar al Ministro de Justicia la dispensa en el caso de la prohibición por muerte dolosa para poder contraer matrimonio, no estamos en un supuesto de indulto sino de una causa impeditiva del ejercicio de un derecho constitucional; ni el legislador ha precisado qué circunstancias podrían concurrir para que procediese la misma, más allá

${ }^{1}$ La dispensa de impedimento de parentesco puede tener lugar cuando exista «una convivencia prolongada y voluntaria entre tío y sobrina (...) pueda ser tal fuente de afecto que llegue a la affectio maritalis», RDGN 18 de octubre de 1995. 
de indicar esta posibilidad a instancia de parte (art. $48.1 \mathrm{CC}$ ). Se otorga así a la Administración una suerte de discrecionalidad para apreciar dicha dispensa, cuando en un Estado de Derecho corresponde siempre a los órganos jurisdiccionales acordar la limitación o suspensión del ejercicio de derechos.

Aunque pudiera resultar inicialmente más comprensible otorgar al Juez de Primera Instancia la facultad de dispensar «los impedimentos del grado tercero entre colaterales y de edad a partir de catorce años», la invocación a la «justa causa»-concepto jurídico obviamente indeterminado a priori-sitúa al órgano jurisdiccional ante un margen de discrecionalidad posiblemente excesivo para apreciar la misma, con el riesgo que a tal efecto se puede derivar de dejar el ejercicio del derecho a contraer el matrimonio a la apreciación de la concurrencia de la citada causa, interpretable de forma heterogénea por el órgano jurisdiccional ${ }^{2}$.

\subsection{La intervención del Encargado del Registro Civil y el alcance del control sobre los contrayentes en los supuestos de matrimonio de complacencia}

Aun cuando tiene un carácter secundario en esta materia, existe otra prohibición de contraer matrimonio en la que hemos de reparar; nos referimos al matrimonio de complacencia, que encierra una suerte de presunción de intención evidente de cometer un fraude de ley para la consecución de otros objetivos: la regularización del inmigrante en situación administrativa irregular, la obtención del permiso de residencia, la reagrupación familiar, etc. Recuérdese que «la condición, término o modo del consentimiento se tendrá por no puesta» (art. 45.2 CC). Produce además la confusión de dos planos inicialmente diversos, la situación administrativa del inmigrante y su control conforme al ordenamiento vigente y, por otro lado, el ejercicio de un derecho reconocido al hombre y a la mujer, sin restricción alguna a la nacionalidad de los mismos. Además, las competencias otorgadas a los Encargados del Registro Civil posibilitan llevar a cabo un procedimiento cuasi inquisitorial a los futuros contrayentes al objeto de conocer la veracidad de sus intenciones ${ }^{3}$. En este sentido baste recordar la Instrucción de 31 de enero de 2006, de la Dirección General

${ }^{2}$ La apreciación de la justa causa se produce oído el menor y sus padres en el trámite de audiencia. Atendiendo a la casuística puede apreciarse la justa causa a tenor de la existencia de un embarazo, la ausencia de consentimiento de los padres, la falta de recursos económicos, la edad del menor que viva independientemente alcanzados los 17 años, en suma atendiendo al «nivel de madurez del menor».

3 «es necesario que el Encargado del Registro alcance un convencimiento o convicción plena en el sentido de concluir la veracidad del conjunto de la prueba de las audiencias practicadas con un juicio conclusivo de probabilidad cualificada en grado de certeza moral plena sobre la veracidad del hecho de haber mediado un consentimiento simulado, descartando los casos de mera verosimilitud y los de duda o simple probabilidad». 
de los Registros y del Notariado, sobre los matrimonios de complacencia. La cuestión que suscita esta regulación no es otra que la naturaleza del control de la autorización del matrimonio que más allá de los datos que se puedan obtener durante la investigación o informaciones que procedan de documentos a los que se pueda acceder, se basará en las declaraciones de los interesados o de terceras personas. Cabe preguntarse ¿cuál es el límite legal a la celebración del matrimonio de complacencia? Esto es, ¿existen límites constitucionales a los posibles controles estatales a la hora de celebrar el matrimonio?

Estamos ante una regulación del ejercicio del derecho a contraer matrimonio pensada para procesos de regularización de una situación administrativa sujeta a la ley de extranjería y no exclusivamente para el ejercicio de dicho derecho en el ámbito civil. Por tanto, cabe preguntarse si ¿el estatuto jurídico del extranjero regulado por la ley de extranjería incide en la capacidad para ejercer el derecho a contraer matrimonio? En tal caso, la consideración administrativa de extranjero irregular, a tenor de la vigente legislación en extranjería, constituiría un obstáculo al libre ejercicio del derecho a contraer matrimonio con una persona de nacionalidad española. No obstante hemos de recordar la estrecha relación entre el libre desarrollo de la personalidad reconocido en el marco constitucional y la voluntad de contraer matrimonio. Por tanto, el debate no estaría tanto en el ámbito de la titularidad de los derechos de los extranjeros en nuestro país, como en la constatación de la veracidad de la voluntad de contraer matrimonio manifestada por estos. El control que ha de realizar el Encargado del Registro Civil, esencialmente a través de la entrevista de los contrayentes y los datos e información que éstos puedan aportar respectivamente de ambos futuros contrayentes ¿en qué medida no constituye una intromisión en derechos fundamentales de los futuros contrayentes? La protección constitucional del derecho a la intimidad (art. $18 \mathrm{CE}$ ) alcanza a todas las personas más allá de su carácter nacional o extranjero y puede quedar en precario en el interrogatorio previo para determinar el consentimiento matrimonial. La cláusula de orden público podría argüirse como justificación de la prohibición de los matrimonios poligámicos, pero no así en el caso de aquellos en los que uno de los contrayentes es extranjero y carece de residencia legal.

Evidentemente la intervención del encargado del Registro debe dirigirse a conocer la voluntad real de los contrayentes y su encaje en el marco normativo. El derecho a la vida en familia y la intimidad familiar se contiene expresamente para los extranjeros residentes en el artículo 16 de la Ley Orgánica sobre derechos y libertades de los extranjeros en España y su integración social. A partir de aquí, la misión encomendada al encargado del Registro civil es la de constatar la autenticidad de la voluntad de contraer matrimonio, sin interés ajeno al estricto marco contemplado en los artículos 67 y 68 CC. Pero constatar la simulación de la voluntad, de la intencionalidad o conveniencia del matrimonio, es decir que no concurre un verdadero consentimiento matrimonial, requiere más allá de la deducción tras la entrevista, de una 
presunción a partir de determinados aspectos o circunstancia de las que ya se ha ocupado el legislador comunitario al objeto de impedir los matrimonios de conveniencia ${ }^{4}$. Por tanto, en ausencia de una prueba concluyente de la voluntad de simulación, parecería en principio más adecuado llevar a cabo la inscripción en el registro del matrimonio interesado.

En cualquier caso, siempre conforme a lo previsto en el Código Civil cabe instar la nulidad de dicho matrimonio, bien por el Ministerio Fiscal, bien por el contrayente que hubiera sufrido el engaño, incluso por tercero que hiciese valer un interés legítimo. En efecto, será nulo «cualquiera que sea la forma de su celebración el matrimonio celebrado sin consentimiento matrimonial» (art 73.1 CC), y así un consentimiento simulado supone una voluntad matrimonial inexistente en la que la voluntad expresada no se corresponde con la interna. Obviamente las consecuencias que se derivan de la consideración de la celebración de matrimonio fraudulento conllevará la retirada, revocación o no renovación del permiso de residencia o la autorización de residencia por causa de matrimonio del nacional del país tercero. Es por ello que la referida Instrucción de 31 de enero de 2006, de la Dirección General de los Registros y del Notariado, pivota, de un lado en la consideración de «derecho fundamental de la persona al matrimonio» y de otro, en el impedimento del fraude legislativo tanto en el ámbito del derecho público como en la esfera del derecho privado, siempre que quede constatado el vicio en el consentimiento.

\subsection{Concepto constitucional del matrimonio}

Aun cuando en el primer párrafo del artículo $32 \mathrm{CE}$ se reconoce el derecho a contraer matrimonio "con plena igualdad jurídica», es el mandato al legislador para que lleve a cabo la regulación de «las formas de matrimonio» lo que debe recabar nuestra atención. Inicialmente, como es sabido, la regulación del matrimonio se contiene en el Código Civil, si bien el legislador ha introducido una novedosa regulación de los matrimonios homosexuales en virtud de la Ley 13/2005. No existe, sin embargo, una regulación estatal de las uniones de hecho, pero sí normas autonómicas que han recogido diversos aspectos relativos a efectos jurídicos que se pudieran derivar de su inscripción en registros autonómicos ${ }^{5}$.

${ }^{4}$ Resolución del Consejo de 4 de diciembre de 1997 sobre las medidas que deberán adoptarse en materia de lucha contra los matrimonios fraudulentos. Entre otros no mantenimiento de la vida en común, el hecho de que los contrayentes no se hubieran conocido con antelación, no compartan una lengua que les permita la comunicación, existan antecedentes en alguno de ellos respecto de matrimonios fraudulentos o irregularidades en materia de residencia.

5 Desde 1998 (Ley 10/1998, sobre Uniones Estables de Pareja, en Cataluña) hasta hoy se han aprobado normas sobre parejas de hecho en diversas Comunidades Autónomas 
Pero frente a este modelo tradicional o «histórico» de matrimonio, la realidad social ha demostrado la expansión de una fórmula diferencial, basada en la unión de personas del mismo sexo ${ }^{6}$.

La primera cuestión que se puede avanzar se debería centrar en dilucidar si se trata de relaciones sustancialmente diferentes en un plano jurídico, que merecen por tanto un tratamiento normativo asimismo diverso.

En todo caso, y al margen de distinciones esencialmente conceptuales entre posibles formas matrimoniales o modelos de familia, la idea central que sugiere de forma imperativa el texto constitucional, como ya se ha apuntado, es la de la igualdad entre el hombre y la mujer en el seno de aquellas instituciones de derecho privado.

Tradicionalmente ha sido objeto de atención tanto por parte del legislador como por la jurisprudencia (constitucional y ordinaria) la consideración diferente del matrimonio y la unión de hecho a través de la convivencia «more uxorio», junto con el reconocimiento expreso de la capacidad de elección de las personas de distinto sexo respecto del ejercicio del derecho a contraer matrimonio.

La realidad normativa que introduce la Ley $13 / 2005$, por la que se modifica el Código Civil en materia del derecho a contraer matrimonio, va a permitir la posibilidad de contraer matrimonio a personas del mismo sexo, en atención principalmente al cambio socio-cultural que se ha producido en nuestra sociedad en los últimos años.

La doctrina emanada del Tribunal Europeo de Derechos Humanos (TEDH) suministra un primer argumentario sobre algunos de los problemas que plantean la proyección sobre el ordenamiento de las nociones constitucionales de familia y matrimonio.

La configuración del derecho al respeto a la vida privada y familiar (art. 8 $\mathrm{CEDH})^{7}$, cuyo contenido es más amplio que el del reconocido constitucionalmente de la intimidad personal y familiar (art. 18.1 CE), va a tener una rele-

(Aragón, Baleares, Navarra, Andalucía, Valencia, Madrid, Asturias, Andalucía, Canarias). Esta legislación autonómica se ha amparado en competencias que podríamos denominar como «colaterales» (orientación y planificación familiar) a la materia legislación civil, atribución exclusiva del Estado (art. 149-1.8, CE), salvo en aquellas Comunidades donde existan regímenes forales.

${ }^{6}$ «el sistema familiar actual es plural, es decir, que desde el punto de vista constitucional, tienen la consideración de familias aquellos grupos o unidades que constituyen un núcleo de convivencia, independiente de la forma que se haya utilizado para formarla y del sexo de sus componentes, siempre que se respeten las reglas constitucionales»(STS 12 de mayo de 2011).

7 «Toda persona tiene derecho al respeto de su vida privada y familiar, de su domicilio y de su correspondencia. No podrá haber injerencia de la autoridad pública en el ejercicio de este derecho, sino en tanto en cuanto esta injerencia esté prevista por la ley y constituya una medida que en una sociedad democrática, sea necesaria entre otras para la seguridad nacional, pública, de los bienes, la defensa del orden, etc». 
vancia incuestionable en nuestro ordenamiento interno y jurisprudencia. Desde fecha temprana el TEDH llevó a cabo una interpretación de la familia incompatible con una diferenciación jurídica sustancial entre familia legítima e ilegítima, abordando además toda una serie de cuestiones relativas al procedimiento para determinar la filiación, la extensión de las relaciones familiares del menor y los derechos patrimoniales de éste y de su madre.

Hemos de destacar el tratamiento diferenciado de la protección a la familia (art. 8) y el derecho a contraer matrimonio (art. 16) que depara el CEDH. Así respecto de la consideración de las formas de familia el TEDH ha afirmado «cuando el Estado establece en su ordenamiento jurídico interno el régimen aplicable a ciertos vínculos familiares, tales como los que existen entre una madre soltera y su hijo, debe actuar en todo caso de forma que los interesados puedan desarrollar una vida familiar normal ${ }^{8}$. Por tanto, la noción de familia que se toma en consideración «no se limita a las relaciones basadas en el matrimonio y puede englobar otras relaciones familiares de hecho»; más aún, a juicio de este Tribunal, «existe por tanto entre el niño y sus padres una relación constitutiva de vida familiar incluso si en la época de su nacimiento los padres no vivían ya juntos o habían terminado su relación $»^{9}$. Hemos de recordar también que la orientación sexual constituye «uno de los aspectos más íntimos de la vida privada» ${ }^{10}$.

En relación con la institución matrimonial y el derecho a contraer matrimonio (art. 12, CEDH) ${ }^{11}$, la Corte de Estrasburgo ha venido a señalar un componente sociocultural ineludible para cualquier operador jurídico: «el matrimonio posee connotaciones sociales y culturales profundamente enraizadas susceptibles de diferir notablemente de una sociedad a otra. Obedece a leyes nacionales de los Estados contratantes, pero las limitaciones resultantes no deben restringirlo o limitarlo de una forma o un grado que perjudicarían su misma esencia $\rangle^{12}$.

En concreto la existencia de distintos regímenes matrimoniales en los Estados Parte ha posibilitado un entendimiento diferenciado de ambas cuestiones. Por lo que a la interpretación de este precepto se refiere, constituye un ejemplo más del carácter evolutivo de la jurisprudencia del TEDH, como reflejo de la evolución social en la materia, que ha dado entrada a formas de convivencia more uxorio, al derecho al matrimonio de los transexuales y a la protección de los hijos habidos fuera del matrimonio entre otras cuestiones novedosas en el ámbito de las relaciones familiares ${ }^{13}$.

${ }^{8}$ Caso Marckx contra Bélgica, STEDH de 13 de junio de 1979.

9 Caso Keegan contra Irlanda, STEDH de 26 de mayo de 1994.

${ }^{10}$ Caso Smith y Grandy contra Reino Unido, STEDH de 27 de septiembre de 1999.

11 «A partir de la edad núbil, el hombre y la mujer tienen derecho a casarse y a fundar una familia según las leyes nacionales que rijan el ejercicio de este derecho».

${ }_{12}$ Caso Muñoz Díaz contra España, STEDH de 8 de diciembre de 2009.

${ }^{13}$ La casuística que presenta la jurisprudencia en interpretación y aplicación de este precepto es diversa y ha operado una sustancial evolución cuando ha debido pronunciarse 
De este modo, y frente al silencio del CEDH sobre un concepto alternativo al tradicional del matrimonio, el TEDH considera compatible con la mencionada norma internacional, el ejercicio por parte de los Estados de un notable «margen de apreciación» a la hora de definir la noción jurídica de matrimonio, respetando de este modo las diferentes características de cada sociedad $^{14}$.

Es cierto que algunas otras cuestiones objeto de debate -colaterales pero igualmente significativas para el caso de estudio- han sido tratadas por el TEDH, cuya jurisprudencia puede actuar de orientación en la resolución de las cuestiones que aquí se plantean. Así respecto de la «incriminación de las relaciones homosexuales» ya se señaló por el TEDH que «constituye una violación del derecho a la vida privada» ${ }^{15}$, afirmación esta que se ha visto complementada con la consideración desde la perspectiva de la discriminación proscrita por el artículo 14 del CEDH de la orientación sexual ${ }^{16}$.

Todavía en el ámbito de las declaraciones internacionales de derechos, tampoco ofrece aportaciones significativas la Carta de Derechos Fundamentales de la Unión Europea ${ }^{17}$, más allá de actualizar el art. 13 del CEDH, de tal modo que no cabe deducir de este otro parámetro convencional ni una prohibición expresa ni un reconocimiento de «la unión de personas del mismo sexo».

El legislador español ha integrado la doctrina del TEDH sobre la acomodación de la norma a la realidad social, respecto a las distintas opciones de orientación sexual; de otro lado, se ha afirmado la relación entre esta última y el libre desarrollo de la personalidad. Como se recoge en la Exposición de Motivos de la Ley 3/2007 reguladora de la rectificación registral de la mención relativa al sexo de las personas, «la transexualidad constituye una reali-

el TEDH sobre la edad legal para contraer el matrimonio, superior en algún caso a la establecida en el culto religioso, sobre la inexistencia de un derecho al divorcio en el CEDH o sobre el matrimonio entre transexuales. Casos Johnston y otros contra Irlanda, STEDH de 18 de diciembre de 1986 y Christine Goodwin contra el Reino Unido, STEDH de 11 de julio de 2002

${ }_{14}$ Véanse a propósito de esta interpretación, las resoluciones dictadas, sobre el derecho al matrimonio entre personas del mismo sexo en el Caso Schalk y Kopf contra Austria, STEDH de 22 de noviembre de 2010; respecto del matrimonio de transexuales Caso Christine Goodwin contra Reino Unido, STEDH de 11 de julio de 2002; Caso I. contra Reino Unido, STEDH de 11 de julio de 2002 y Caso Parry contra Reino Unido y Caso R. y F. contra Reino Unido, SSTEDH de 28 de noviembre de 2006.

${ }_{15}$ Caso Duelguen contra Reino Unido, STEDH 22 de octubre de 1981.

${ }_{16}$ Caso Salgueiro de Silva Mouta contra Portugal, STEDH de 21 de marzo de 2000.

17 Artículo 9 de la Carta de Derechos Fundamentales de la Unión Europea: «Derecho a contraer matrimonio y derecho a fundar una familia. Se garantizan el derecho a contraer matrimonio y el derecho a fundar una familia según las leyes nacionales que regulen su ejercicio». 
dad social que requiere una respuesta del legislador, para que la inicial asignación registral del sexo y del nombre propio puedan ser modificadas, con la finalidad de garantizar el libre desarrollo de la personalidad y la dignidad de las personas cuya identidad de género no se corresponde con el sexo con el que inicialmente fueron inscritas».

En cuanto a la doctrina del Tribunal Constitucional, no disponemos de una construcción jurisprudencial definitiva sobre el concepto de familia, si bien parece obvio que éste no está reservado sólo al matrimonio tradicional ni a la existencia de descendencia, del mismo modo que se aplica esa noción constitucional a la existencia de familias extramatrimoniales o monoparentales.

En efecto, la aproximación realizada por el Alto Tribunal a esta cuestión tiene como punto de partida la igualdad de las personas. En primer lugar, debemos recordar la doctrina emanada del Tribunal Constitucional respecto de la igualdad comprende la cláusula general de la igualdad y la necesidad de justificar la diferencia de trato. Desde este Tribunal se ha distinguido entre la cláusula general de igualdad (art. 14.1) «por la que se confiere un derecho subjetivo a todos los ciudadanos a obtener un trato igualitario de los poderes públicos, siempre que concurran supuestos idénticos y no existan razones que objetivamente justifiquen la diferenciación». La interpretación del segundo apartado del art. $14 \mathrm{CE}$ se concreta en la prohibición de la práctica de comportamientos discriminatorios basados en alguno de los factores que se contienen en el mismo; un listado que tiene solamente carácter enunciativo y, por tanto, no está cerrado.

En este ámbito es donde podría traerse a colación el pronunciamiento del TC a propósito de la condición de transexual, que - afirma - «si bien no aparece expresamente mencionada en el art. $14 \mathrm{CE}$ como uno de los concretos supuestos en que queda prohibido un tratamiento discriminatorio, es indudablemente una circunstancia incluida en la cláusula «cualquier otra condición o circunstancia personal o social» a la que debe ser referida la interdicción de la discriminación» (STC 176/2008).

Los pronunciamientos del Tribunal Constitucional han defendido la tesis de que convivencia y matrimonio no son realidades equivalentes ${ }^{18}$ (STC $184 / 1990^{19}$ y 47/1993). Sin embargo, esta diferencia no ha impedido a la ju-

18 «Nuestra Constitución no ha identificado la familia a la que manda proteger con la que tiene su origen en el matrimonio (...) el sentido de estas normas constitucionales no se concilia, por tanto, con la constricción del concepto de familia a la de origen matrimonial, (...) existentes otras junto a ella, como corresponde a una sociedad plural» (STC 222/1992).

19 Se trata de una cuestión de inconstitucionalidad promovida en relación el art. 160 de la Ley General de la Seguridad Social y con la disposición adicional décima, de la Ley 30/1981 por la que se modifica la regulación del matrimonio en el Código Civil y se determina el procedimiento a seguir en las causas de nulidad, separación y divorcio. La obtención de una pensión de viudedad quedaba condicionada a la existencia de vínculo 
risprudencia constitucional tomar posición en favor de otorgarles efectos jurídicos análogos en algunas dimensiones; como por ejemplo el reconocimiento de la percepción de pensiones en parejas de hecho (STC 184/1990) como en la reciente STC 41/2013 que ha declarado la inconstitucionalidad de la disposición adicional tercera de la ley General de la Seguridad Social, o la subrogación arrendaticia por miembros de la unión de hecho (STC 222/1992) ${ }^{20}$. En el mismo sentido se debe recordar que la Ley 35/1988 sobre Técnicas de reproducción asistida permite la fertilización de cualquier mujer con independencia de que el donante sea o no su marido, tenga vínculo matrimonial o carezca de él. La constitucionalidad de esta norma fue reafirmada por el TC ya que no vulnera el núcleo esencial de la institución familiar.

Por otra parte, la elección de vida y la orientación sexual han tenido y tienen una amplia relevancia en el tratamiento constitucional de las relaciones en el ámbito familiar, lo que a su vez debe tener un reflejo legislativo y jurisprudencial en el ámbito del derecho civil.

La comprensión última de esta actualización en el tratamiento del derecho de familia y la adecuación a la Constitución de otras formas de matrimonio se contiene en la STC 198/2012 que pone fin al recurso de inconstitucionalidad contra la Ley 13/2005. Nuestro Alto Tribunal sitúa el debate a partir de la afirmación de que «la institución del matrimonio como unión entre dos personas independientemente de su orientación sexual se ha ido asentando», lo que nos permite desde la perspectiva del derecho comparado «entender hoy la concepción del matrimonio (...) como una concepción plural». Ciertamente la condición de las personas que conforman el matrimonio, cualquiera que sea su configuración: heterosexual u homosexual, no constituye objeción alguna para la determinación del régimen económico matrimonial,

matrimonial entre causante y beneficiario de la misma, quedando exonerados de tal exigencia tan solo quienes no hubieran podido contraer matrimonio por impedírselo la legislación anterior a la Ley 30/1981. El TC había señalado que puesto que el derecho a contraer matrimonio es un derecho constitucional, nada impediría inicialmente que por parte del legislador se estableciesen diferencias de tratamiento entre la unión matrimonial y la meramente fáctica. Ahora bien, nada impediría que se extendiese a las uniones estables de hecho los beneficios de la pensión de viudedad bajo determinadas condiciones. Concluye el Alto Tribunal señalando que siendo admisible esta opción no cabe reproche de inconstitucionalidad a la regulación vigente en aquel momento.

${ }_{20}$ Para el TC, en este último supuesto, esa equiparación entre la respectiva situación de los miembros supérstites de la pareja matrimonial y la no matrimonial era necesaria, ya que el beneficio recogido en el artículo 58.1 de la LAU lo era de la subrogación al «cónyuge» del arrendatario fallecido («al fallecimiento del inquilino titular del contrato de arrendamiento, su cónyuge (..) podrá subrogarse en los derechos y obligaciones del arrendamiento»). La conclusión que se alcanza es la de la inconstitucionalidad del art. 58.1 de la Ley de Arrendamientos Urbanos (Texto Refundido aprobado por Decreto 4104/1964) en la medida en que «excluye del beneficio de la subrogación mortis causa a quien hubiere convivido de modo marital y estable con el arrendatario fallecido» (STC 222/1992). 
régimen de derecho sucesorio, llamamiento preferente para desempeñar la representación del ausente, tutela o curatela.

El TC había acudido con antelación a los precedentes recogidos en la jurisprudencia del TEDH para configurar el estatus jurídico de derechos de las parejas homosexuales ante determinadas situaciones relevantes para el ordenamiento, tal y como sucedió con la STC 184/1990 relativa al reconocimiento de la pensión de viudedad. A tal efecto podemos recordar también el inequívoco pronunciamiento de nuestro Alto Tribunal al afirmar que «se debe admitir la plena constitucionalidad del principio heterosexual como calificador del vínculo matrimonial, tal como prevé nuestro Código Civil, de tal manera que los poderes públicos pueden otorgar un trato de privilegio a la unión familiar constituida por hombre y mujer frente a la unión homosexual, lo cual no excluye que se pueda establecer por el legislador un sistema de equiparación por el que los convivientes homosexuales puedan llegar a beneficiarse de los plenos derechos y beneficios del matrimonio» (ATC 222/1994).

Así pues, el supremo intérprete de la Constitución viene a considerar que el principio heterosexual del matrimonio es una opción más del legislador dentro del marco constitucional, si bien resultan también constitucionalmente legítimas otras posibles opciones. En este sentido, la doctrina que emana de la STC 198/2012 va a determinar si la opción del legislador contenida en la Ley 13/2005 tiene acomodo dentro de nuestro régimen constitucional. A tal fin reconoce que dicha ley ha supuesto la modificación de las condiciones de ejercicio del derecho constitucional a contraer matrimonio, dentro de la tendencia refrendada tanto por la jurisprudencia del TEDH como del derecho comparado, a la equiparación del estatuto jurídico de las personas homosexuales y heterosexuales.

Ahora bien, - a juicio del TC- esta modificación operada por el legislador no lo es en el sentido impeditivo o restrictivo para las personas heterosexuales, cuanto sí lo es en sentido positivo, es decir, amplía la posibilidad de su ejercicio para toda persona del mismo o diferente sexo. Se ha efectuado ciertamente una alteración del régimen de ejercicio del derecho constitucional al matrimonio, pero sin afectar el contenido esencial de este último, de modo que en la nueva redacción contenida en la Ley 13/2005 el «derecho individual a contraer matrimonio integra también el respeto a la propia orientación sexual». Esta ampliación del concepto de matrimonio supone, para nuestro Alto Tribunal, una constatación más de la garantía de la dignidad de la persona y el libre desarrollo de la personalidad en orden a la consecución de la plena efectividad de los derechos fundamentales (STC 198/2012).

A modo de conclusión podemos recordar con el Tribunal Supremo que «El sistema familiar actual es plural, es decir, que desde el punto de vista constitucional, tiene la consideración de familias aquellos grupos o unidades que constituyen un núcleo de convivencia, independiente de la forma que se haya utilizado para formarla y del sexo de sus componentes, siempre que se respeten las reglas constitucionales» (STS 12 de mayo de 2011). 


\subsection{Las Uniones de Hecho}

Pero los supuestos susceptibles de análisis relativos a la familia no se agotan con los ya expuestos. En todo caso subsiste, a efectos civiles, la duda respecto de las uniones de hecho y su adecuación al principio de igualdad en relación con la regulación de los derechos de los miembros del matrimonio. No podemos desconocer las consecuencias que de estas uniones se pueden derivar para sus integrantes en diversos ámbitos como en orden a la seguridad social y las pensiones, fiscalidad, empleo y en su caso prestaciones por desempleo, en cuestiones relativas a la educación, en arrendamientos, etc.

Es cierto que se ha de formular una advertencia respecto a su regulación atendiendo a la existencia de un ordenamiento foral propio en el territorio en consideración o el régimen común del Código Civil. Será a éste último al que atenderemos en estas páginas si bien indicando que las leyes autonómicas que han contemplado su regulación, han incluido entre los requisitos para la consideración de las mismas por la administración, la existencia de convivencia efectiva durante un tiempo determinado, la inscripción en el registro de las uniones de hecho creadas por la respectiva ley autonómica de su normación, la existencia de la declaración formulada para dejar constancia de su constitución ${ }^{21}$ e incluso, en algún caso, la existencia de hijos habidos durante la convivencia. En todo caso se ha de atender a lo afirmado por el Tribunal Constitucional en la reciente STC 81/2013 que ha resuelto una cuestión de inconstitucionalidad planteada por la Sala de lo Contencioso-Administrativo del Tribunal Superior de Justicia de Madrid en relación con diversos preceptos de la Ley de la Asamblea de Madrid 11/2001, de 19 de diciembre, de uniones de hecho. La cuestión viene referida, entre otros preceptos, a la regulación por el legislador autonómico de la convivencia de las parejas de hecho (art. $4^{22}$ ), y su inscripción (art. $5^{23}$ ). Pues bien, nuestro Alto Tribunal entiende

21 «tendrán la condición de parejas de hecho las uniones de dos personas mayores de edad, capaces, que convivan con la intención o vocación de permanencia en una relación de afectividad análoga a la conyugal y que la inscriban en el Registro de parejas de hecho de Galicia, expresando su voluntad de equiparar sus efectos a los del matrimonio», apartado segundo de la disposición adicional tercera de la Ley 20/2007, de 28 de junio, de reforma de la disposición adicional tercera de la Ley 2/2006, de 14 de junio, de derecho civil de Galicia.

22 «Art. 4 1. Los miembros de la unión de hecho podrán establecer válidamente en escritura pública los pactos que consideren convenientes para regir sus relaciones económicas durante la convivencia y para liquidarlas tras su cese.

2. Los pactos a que se refiere el número anterior podrán establecer compensaciones económicas cuando, tras el cese de la convivencia se produzca un desequilibrio económico en uno de los convivientes con relación a la posición del otro que implique un empeoramiento respecto a la situación anterior. Tales compensaciones habrán de tomar en consideración las mismas circunstancias a que se refiere el art. 97 del CC.»»

${ }^{23}$ «Art. 5 1. Los pactos a que se refiere el artículo 4 podrán inscribirse en el Registro, siempre que en ellos concurran los requisitos de validez expresados en el mismo artículo. 
que esta regulación viene referida al ámbito de las relaciones personales y patrimoniales de los integrantes de la unión de hecho y, por ello, una naturaleza propia de la materia regulada por el derecho civil con la consiguiente competencia exclusiva sobre legislación civil del Estado lo que conduce a declarar la inconstitucionalidad de dichos preceptos.

Con apoyo en la jurisprudencia del Tribunal Supremo podemos caracterizar las uniones de hecho como una realidad social que reúne entre otros los siguientes requisitos: «constitución voluntaria, estabilidad, permanencia en el tiempo, con apariencia pública de comunidad de vida similar a la matrimonial»(STS de 17 de junio de 2003). Pues bien, esta realidad social ha sido merecedora de reconocimiento »como una modalidad de familia, aunque sin equivalencia con el matrimonio, por lo que no cabe trasponerle el régimen jurídico de éste, salvo en algunos aspectos» (STS de 12 de septiembre de 2005), aunque el hecho de operar sus integrantes fuera del matrimonio no implica que la existencia de éstas o su ruptura no tengan importantes consecuencias jurídicas.

Son diversas las cuestiones que pueden resultar polémicas respecto de las consecuencias jurídicas de las uniones de hecho; desde la exigencia de formalidad para determinar su existencia a través del requisito de su inscripción en el registro autonómico consiguiente, hasta la disparidad normativa de su regulación, que se ve afectada por la existencia de normativa foral propia en algunos casos y, sin duda, por la ausencia de legislación estatal sobre las parejas de hecho.

Como antes se ha señalado, la ausencia de legislación estatal sobre uniones de hecho no obsta para que en determinados casos el propio legislador o la jurisprudencia hayan hecho extensivo determinado reconocimiento de efectos jurídicos a los miembros de la unión de hecho. Sirva como muestra de ello el Real Decreto 288/2003 por el que se aprueba el Reglamento de ayudas y resarcimientos a las víctimas de delitos de terrorismo, que lleva a cabo una equiparación entre cónyuge del fallecido y «la persona que hubiere convivido con ella de forma permanente con análoga relación de afectividad a la del cónyuge, cualquiera que sea su orientación sexual durante al menos los dos años anteriores al momento del fallecimiento, salvo que hubieran tenido descendencia en común, en cuyo caso, bastará la mera convivencia» (art. 7.2.a). Esta orientación está recogida en la Ley 32/1999 de Solidaridad con las víctimas del terrorismo, modificada por la Ley $2 / 2003$, si bien no implica la extensión a las parejas de hecho de otras prestaciones estatales con carácter general ${ }^{24}$.

2. La inscripción podrá efectuarse a petición de ambos miembros de la unión conjuntamente».

${ }^{24}$ «Al margen de que es legítimo que el legislador haga derivar del vínculo familiar determinados efectos, ha de tenerse en cuenta que el legislador tiene amplio margen para 


\subsubsection{La igualdad ante la ley}

Es claro que ante la realidad social que supone hoy en día las uniones de hecho, éstas deben gozar de protección jurídica y evitar en todo caso situaciones de desigualdad o discriminación. En este sentido hemos de detenernos brevemente en el análisis de sendas cuestiones de inconstitucionalidad que ha resuelto el TC relativas a la existencia de vulneración de la igualdad a la luz de la regulación de la pensión de viudedad entre los integrantes de una pareja de hecho.

En primer lugar, nos referimos a la STC 41/2013 que puso fin a la cuestión de inconstitucionalidad planteada por un Juzgado de lo Social respecto de la disposición adicional tercera de la Ley 40/2007, de medidas en materia de Seguridad Social, que modificó el artículo 174 de la Ley General de la Seguridad Social que regula la pensión de viudedad e introdujo una nueva situación objeto de protección, la referida al supérsite de una pareja de hecho que pudiera acreditar la convivencia con el causante por un plazo de tiempo no inferior a 5 años anteriores al fallecimiento y dependencia económica ${ }^{25}$.

Los requisitos exigidos se concretaban más allá de los generales contenidos en la norma ${ }^{26}$ en la necesidad de que el hecho causante hubiera tenido lugar con anterioridad a la entrada en vigor de la misma (1 de enero de 2008) y «que el causante y el beneficiario hubieran tenido hijos comunes». Entiende el Juzgado que plantea la cuestión de inconstitucionalidad que dicho precepto conlleva un trato desfavorable a tenor de la opción sexual que conculca

configurar el sistema de previsión social y regular los requisitos de concesión de determinadas prestaciones en atención a las circunstancias, prioridades, disponibilidades materiales y las necesidades de los diversos grupos sociales (...) No puede excluirse, por ello, que el legislador realice ciertas opciones selectivas (...) de tal manera que no pueden considerarse, sin más, discriminatorias o atentatorias contra el art. $14 \mathrm{CE}$ estas disposiciones selectivas, a menos que las mismas no se amparen en causas y fundamentos razonables» (STC 174/2004).

25 «se considera pareja de hecho la constituida con análoga relación de efectividad a la conyugal, por quienes, no hallándose impedidos para contraer matrimonio, no tengan vínculo matrimonial con otra persona y acrediten, mediante el correspondiente certificado de empadronamiento una convivencia estable y notoria con carácter inmediato al fallecimiento del causante y con una duración ininterrumpida no inferior a 5 años»(art. 174.3, párrafo cuarto).

26 «Con carácter excepcional, se reconocerá derecho a la pensión de viudedad cuando, habiéndose producido el hecho causante con anterioridad a la entrada en vigor de la presente ley, concurran las siguiente circunstancias: a) que a la muerte del causante, reuniendo éste los requisitos de alta y cotización (art. 174.1 «no se hubiera podido causar derecho a pensión de viudedad», b) «que el beneficiario hubiera mantenido convivencia ininterrumpida como pareja de hecho (...) con el causante durante, al menos, los seis años anteriores al fallecimiento de éste» c) «que el causante y el beneficiario hubieran tenido hijos comunes» d) «que el beneficiario no tenga reconocido derecho a pensión contributiva de la Seguridad social». 
el artículo $14 \mathrm{CE}$, dado que la exigencia de tener hijos en común para poder ser destinatario de la pensión de viudedad en los supuestos de parejas de hecho cuyo causante hubiera fallecido con antelación al 1 de enero de 2008 difícilmente podría cumplirse por las parejas de hecho homosexuales. Además se indicaba la imposibilidad hasta fecha reciente de llevar a cabo la adopción conjunta y la adopción individual del hijo del conviviente para las parejas del mismo sexo.

Comienza el TC por recordar que el legislador dispone de un amplio margen de libertad a la hora de llevar a cabo la configuración del sistema de la Seguridad Social y reiterando su doctrina se recuerda que «habrá de ser, en su caso, el legislador quien decida proceder a dicha extensión, con los requisitos y en los términos que se consideren pertinentes, y en el marco de una nueva y coherente ordenación de la citada pensión singularmente si la convivencia establece sin vínculo matrimonial se instalara como una practica social extendida»(STC 184/1990).

Por tanto para la resolución de esta cuestión compete al Alto Tribunal resolver si la diferencia de trato que se deriva del precepto analizado (apartado c, de la disposición adicional tercera de la Ley 40/2007) que establece entre parejas de hecho con hijos en común y parejas de hecho que no hayan tenido hijos comunes, «responde a una finalidad objetivamente justificada, razonable y proporcionada $\rangle^{27}$.

Pues bien, considera el Tribunal que lo determinante de este precepto para el legislador no es otra cuestión que la pareja de hecho haya tenido descendencia en común, lo que constituye una directa vulneración del principio de igualdad ante la ley ya que »la diferencia de trato que se establece por la norma cuestionada entre parejas de hecho, en razón a que hubieran tenido o no hijos en común, no sólo no obedece, (...) a ninguna razón objetivamente justificada (...) sino que conduce además a un resultado desproporcionado, al impedir injustificadamente a determinados supérsites de parejas de hecho el acceso a la protección dispensada mediante dicha pensión, por ser de imposible cumplimiento (por razones biológicas o jurídicas) la exigencia de haber tenidos hijos comunes».

En segundo lugar, hemos de atender a la reciente STC 40/2014 a la luz de la cuestión de inconstitucionalidad planteada por la Sala Cuarta, de lo Social,

${ }^{27}$ Recordemos que el principio de igualdad «no implica en todos los casos un tratamiento legal igual con abstracción de cualquier elemento diferenciador de relevancia jurídica, de manera que no toda desigualdad de trato normativo respecto a la regulación de una determinada materia supone una infracción del mandato contenido en el art. 14. CE, sino tan sólo las que introduzcan una diferencia entre situaciones que puedan considerarse iguales, sin que se ofrezca y posea una justificación objetiva y razonable para ello, pues, como regla general, el principio de igualdad exige que a iguales supuestos de hecho se apliquen iguales consecuencias jurídicas y, en consecuencia, veda la utilización de elementos de diferenciación que quepa calificar de arbitrarios o carentes de una justificación razonable» (STC 39/2002). 
del Tribunal Supremo respecto del párrafo quinto del artículo 174.3 del texto refundido de la Ley General de la Seguridad Social, aprobado por Real Decreto Legislativo 1/1994, de 20 de junio, en la redacción dada por la Ley 40/2007, de 4 de diciembre, de medidas en materia de Seguridad Social ${ }^{28}$. Para la Sala del Tribunal Supremo, este precepto puede vulnerar el principio de igualdad ante la ley previsto en el artículo $14 \mathrm{CE}$ pues puede ocurrir que, estando ante parejas de hecho en idéntica situación fáctica, el derecho reconocido a la pensión de viudedad les será concedido o denegado en función únicamente de la Comunidad Autónoma en que tengan su residencia o vecindad, y más en concreto, en función de si dicha Comunidad Autónoma cuenta o no con derecho civil propio. Constata el Alto Tribunal que, «existen diferencias» entre las normas que regulan las parejas de hecho dictadas por las Comunidades Autónomas con Derecho civil propio y el artículo 174.3 «tanto en la consideración de pareja de hecho como en su acreditación» ${ }^{29}$.

El Tribunal Constitucional señala que «el régimen público de Seguridad Social debe ser único y unitario para todos los ciudadanos y garantizar al tiempo la igualdad de todos los españoles en el ejercicio de los derechos y deberes en materia de seguridad Social, siendo ambos aspectos responsabilidad del Estado (art. 149.1.17 CE)». Por ello, se añade en la sentencia «la determinación de los sujetos beneficiarios de una prestación de la Seguridad Social, en este caso, la pensión de viudedad, constituye una norma básica que corresponde establecer al Estado (...) y debe hacerlo de forma unitaria para todos los sujetos comprendidos dentro de su ámbito de cobertura, salvo razones excepcionales debidamente justificadas o vinculadas a la situación de necesidad que se trata de proteger». Continua el Tribunal reconociendo que el precepto analizado introduce «un factor de diversidad determinante de la desigualdad de trato en el régimen jurídico de la pensión de viudedad» y lleva a «un resultado desproporcionado, pues dependiendo de la Comunidad Autónoma de residencia el superviviente de la pareja de hecho podrá tener o no acceso al cobro de la correspondiente pensión». La conclusión que se alcanza para declarar la inconstitucionalidad del citado precepto es que «no es posible deducir finalidad objetiva, razonable y proporcionada que justifique el establecimiento de un trato diferenciado entre los solicitantes de la correspondiente pensión de viudedad en función de su residencia o no en una Co-

28 «En las Comunidades Autónomas con Derecho civil propio, cumpliéndose el requisito de convivencia a que se refiere el párrafo anterior la consideración de pareja de hecho y su acreditación se llevará a cabo conforme a lo que establezca su legislación específica».

29 «en el caso de la pensión de viudedad, las diferencias en función del criterio de residencia en una u otra Comunidad Autónoma no gozan de esa justificación objetiva, por cuanto no se aprecian razones para deducir que la situación de necesidad en relación a esta prestación es mayor o más grave en las Comunidades Autónomas de Derecho civil propio». 
munidad Autónoma con Derecho Civil propio que hubiera aprobado legislación específica en materia de parejas de hecho».

En este sentido posteriores pronunciamientos del Alto Tribunal, en respuesta a otras cuestiones de inconstitucionalidad planteadas respecto del art. 174.3 de la Ley 40/2007, de medidas en materia de seguridad social, han afirmado la constitucionalidad del establecimiento por el legislador a los efectos del reconocimiento de la pensión de viudedad, del requisito de que los integrantes de la pareja de hecho no tengan vínculo matrimonial con otra persona (STC 44/2014), así como de la exigencia de la previa inscripción registral de la pareja de hecho o su constitución en documento público (SSTC 45 y $51 / 2014)$.

\subsubsection{Posibles efectos en caso de crisis}

La regulación autonómica sobre parejas de hecho ha concretado algunos aspectos del régimen jurídico aplicable a las personas que acuerden constituirse en pareja de hecho, las formalidades de su constitución y acreditación así como el contenido jurídico patrimonial de la relación. En efecto, los convenios y pactos reguladores del régimen económico-patrimonial podrán también inscribirse en el registro autonómico correspondiente, indicándose en ellos los respectivos derechos y deberes así como las compensaciones económicas para el caso de la disolución de la pareja. La jurisprudencia del Tribunal Supremo no ha clarificado en algunos aspectos las consecuencias que se pueden derivar de la existencia de las uniones de hecho ${ }^{30}$.

Resulta quizá de mayor interés detenerse en los posibles efectos para los miembros de la unión de hecho de la crisis y ruptura de la misma. En contraste con las previsiones que se contienen respecto de los efectos comunes a la nulidad, separación y divorcio en el Código Civil, pareciera que en caso de finalizar las uniones de hecho, sería necesario plantear cuestiones como las

${ }^{30}$ Nos hacemos eco aquí de las posiciones concretadas por este Tribunal en la Sentencia de 8 de mayo de 2008 que pueden ser resumidas en los siguientes términos: habrá de estarse en primer lugar «a los pactos que hayan existido entre las partes relativos a la organización económica para la posterior liquidación de estas relaciones. En segundo lugar «No se requiere que el pacto regulador de las consecuencias económicas de la unión de hecho sea expreso (...) se puede colegir la voluntad de los convivientes de hacer comunes todos o algunos de los bienes adquiridos durante la convivencia siempre que pueda deducirse una voluntad inequívoca en este sentido». Señala a continuación el Tribunal que «no puede aplicarse por analogía la regulación establecida para el régimen económico matrimonial porque al no haber matrimonio, no hay régimen». Concluyéndose este pronunciamiento con la afirmación de que «Los bienes adquiridos durante la convivencia no se hacen comunes a los convivientes, por lo que pertenecen a quien los haya adquirido; sólo cuando de forma expresa o de forma tácita se pueda llegar a determinar que se adquirieron en común, puede producirse la consecuencia de la existencia de dicha comunidad». 
relativas al cuidado de los hijos sujetos a la patria potestad, régimen de comunicación y estancia de los hijos, la atribución del uso de la vivienda y ajuar familiar, pensión en caso de desequilibrio económico en relación con la posición del otro miembro de la pareja de hecho, etc. El legislador autonómico ha previsto en algunos casos, entre los efectos del cese de la unión de hecho, la pensión periódica para el miembro de la pareja que la necesitara para atender adecuadamente su sustento, así como una compensación económica a favor del miembro de la pareja que, sin retribución o con retribución insuficiente, haya trabajado para el hogar común o para el otro miembro, en el caso de que se haya generado por este motivo una situación de desigualdad entre el patrimonio de ambos que implique un enriquecimiento injusto ${ }^{31}$.

Más allá de las dudas planteadas en la doctrina, cabe decir que la jurisprudencia del Tribunal Supremo se ha encargado de esta cuestión recogiendo las distintas opciones que se presentan desde «a) las que tiene como principio la regla general de negar efecto económico alguno a favor de uno de los miembros de la pareja para el caso de ruptura. Los efectos económicos serán únicamente, en su caso, los que los propios miembros de la pareja hayan previsto mediante pacto, con la misma libertad con la que decidieron unirse y con los límites generales del art. 1255 CC. En definitiva, a falta de pacto entre los miembros de la unión, cada uno asume las consecuencias económicas de la ruptura». Continua este Tribunal cuestionando el alcance y las consecuencias jurídicas de las uniones de hecho «Cuando se afirma como principio general, en esta materia el de favorecer al miembro «más desprotegido», se omite preguntarse ¿más desprotegido por qué o por quién? Dicho de otra forma, si la «protección» en la que se está pensado es la que brinda el régimen jurídico del matrimonio y este régimen se excluyó consciente y voluntariamente, ¿dónde está la desprotección que jurídicamente haya que remediar?» (STS 12 de septiembre de $2005^{32}$ ).

En todo caso el propio Tribunal repara en el necesario reconocimiento de efectos jurídicos de la ruptura unilateral de las uniones de hecho para añadir que «b) También hay que tener en cuenta las posiciones que se basan en la anterior postura, pero que, sin embargo, afirman que todo lo antedicho no excluye, evidentemente, el reconocimiento de efectos jurídicos de la ruptura unilateral de las uniones de hecho. Pero serán efectos jurídicos derivados o

31 Art. 6.2 de la ley 2/2003, reguladora de las parejas de hecho del País Vasco.

32 «En conclusión y como epítome, se puede decir que en el criterio jurisprudencial de la Sala Primera del Tribunal Supremo en materia de compensación económica no pactada en la ruptura de las parejas de hecho, se puede constatar que la técnica más utilizada es la de la doctrina del enriquecimiento injusto, seguida por la de protección al conviviente más perjudicado por la situación de hecho, más tarde la de la aplicación analógica del art. 97 del Código Civil, y por la de la teoría de la responsabilidad civil extracontractual, y por último la de disolución de la sociedad civil irregular o comunidad de bienes». 
propios de la institución que en cada caso proceda y no precisamente del matrimonio» (STS de 12 de septiembre de 2005). Por tanto, cabe preguntarse ilas normas que rigen en las crisis matrimoniales son trasladables a las rupturas en las uniones de hecho? Aun cuando hay que proteger a la familia, igualmente ocurre con el derecho a la igualdad de los convivientes y por tanto podemos cuestionarnos, entre otros, si ¿tiene derecho el otro conviviente a la atribución de la vivienda en caso de fallecimiento o ruptura de la unión de hecho?

No obstante, la cuestión no termina de ser pacífica pues contamos con pronunciamientos divergentes del Tribunal Supremo respecto de la aplicación, en su caso, de la analogía a las parejas no casadas de las normas reguladoras de los efectos del matrimonio y del divorcio. En concreto el Tribunal Supremo ha afirmado que tras la disolución de la unión de hecho procederá la compensación cuando se produzca un desequilibrio, y que implica un empeoramiento en relación con la situación anterior. Ahora bien, para su correcta apreciación habrá que estar a la existencia, en su caso, de pactos, promesas o la creación y el sostenimiento de «situaciones de facto de las que se pueda deducir que hubo ese proyecto de vida en común y que se ha producido lo que se denomina «pérdida de oportunidad» que sería aquí, el factor de soporte que vendría de algún modo a sustituir al concepto de «empeoramiento» que ha de calificar el desequilibrio». Por tanto, en ausencia de pacto entre los convivientes, deben aplicarse los principios generales del derecho (STS de 12 de septiembre de 2005) ${ }^{33}$.

Sin embargo, el Tribunal Supremo ha afirmado en otras sentencias que «debe huirse de la aplicación por analogia legis de normas propias del matrimonio» como son los artículos 96, 97 y $98 \mathrm{CC}$, abandonando la doctrina contenida en la STS de 12 de septiembre de 2005 «para acogerse a la no aplicación por analogía a las parejas no casadas, de las normas reguladoras de los efectos del matrimonio y del divorcio» (STS de 6 de octubre de 2011).

Podemos plantearnos $i$ si la crisis de la convivencia de hecho es equiparable en relación al domicilio con las crisis matrimoniales? En caso de resolver sobre la asignación de la vivienda familiar en una unión de hecho en situación de crisis, tratándose de vivienda de propiedad exclusiva de uno de los miembros de la unión, adquirida durante la vigencia de la unión, ¿se deberían adoptar los mismos criterios que se aplican en casos de crisis matrimoniales, o bien otros diferentes? ¿qué sucedería en caso de interponerse por el propietario una demanda de desahucio? En función de la respuesta podemos interrogarnos sobre si el miembro de la pareja que no es titular de la vivienda

${ }^{33}$ El Tribunal Supremo ha admitido la aplicación analógica de reglas propias del matrimonio (art. 96) en relación con la asignación de la vivienda (SSTS 16 de diciembre de 1996, 10 de marzo de 1998, 27 de marzo de 2001 y 1 de abril de 2011) así como en relación con la pensión compensatoria (art. 97) en las SSTS de 5 de julio de 2001 y 16 de julio de 2012. 
puede ser considerado un simple precarista a efectos de la posesión de la vivienda? El Tribunal Supremo ha resuelto que ante la ocupación de vivienda propiedad de su expareja por conviviente de hecho tras la ruptura de la unión estable, no existe norma legal que legitime la continuidad en su uso, y ha considerado adecuado el juicio verbal de desahucio para instar la desocupación de la vivienda privativa por conviviente una vez producida la ruptura de la pareja (STS 6 de octubre de 2011).

Aun cuando no tiene encaje en las uniones de hecho stricto sensu hemos de realizar una breve referencia al matrimonio contraído por el rito gitano por cuando constituye una suerte de realidad sociológica en nuestro país y ha sido objeto de un tratamiento diverso por el TC y el TEDH. Recuérdese que nuestro Alto Tribunal se pronunció con ocasión de una reclamación de pensión de viudedad en un supuesto de matrimonio según el rito gitano y en cuyo recurso de amparo, ulterior a su reivindicación ante los órganos jurisdiccionales, se argumentaba una hipotética vulneración del derecho a la igualdad. El Alto Tribunal desestimó dicho recurso por considerar que el acceso al vínculo matrimonial contemplado en nuestro ordenamiento «es neutral desde la perspectiva racial, al carecer por completo de cualquier tipo de connotación étnica» ${ }^{34}$, no obstante la sentencia contiene un voto particular. El parecer del TEDH sin embargo es diverso ya que «la prohibición de discriminación consagrada en el artículo 14 del CEDH solo tiene sentido si, en cada caso concreto, se tienen en cuenta los criterios enumerados por esta Disposición en relación con la situación personal del demandante. Un enfoque contrario, consistente en denegar el derecho a la víctima por entender que habría podido eludir la discriminación modificando uno de los elementos litigiosos -por ejemplo, casándose civilmente- vaciaría de contenido el art. $14 »^{35}$.

\section{LA ADOPCIÓN LLEVADA A CABO POR LAS PAREJAS HOMOSEXUALES A LA LUZ DE LA STC 198/2012}

La sentencia que puso fin al recurso de inconstitucionalidad contra diversos artículos de la Ley 13/2005 se refiere igualmente a algunas materias que

${ }^{34}$ «no supone una discriminación por razones sociales que el legislador limite la prestación de viudedad a los supuestos de convivencia institucionalizada como casados, excluyendo otras uniones o formas de convivencia (...) ninguna vulneración del art. 14 CE desde esta concreta perspectiva se deriva de la limitación de dicha prestación a la concurrencia de vínculo matrimonial» (STC 69/2007).

35 «El Tribunal considera desproporcionado que el Estado Español, que ha reconocido el estatus de familia numerosa, les ha concedido a la interesada y a sus seis hijos, una asistencia en materia sanitaria, y que ha percibido las cotizaciones de su marido gitano a la Seguridad Social durante más de 20 años, no quiera hoy en día reconocer los efectos del matrimonio gitano en materia de pensión de viudedad». Caso Muñoz Díaz contra España, STEDH 8 de diciembre de 2009. 
afectan al principio rector del artículo 39 CE (protección de la familia y los hijos). La cuestión controvertida que se suscita en el recurso de inconstitucionalidad formulado a la Ley 13/2005 es la relativa a la voluntas legislatoris, donde se marca una orientación clara en orden a poner fin a la discriminación de parejas homosexuales frente a las heterosexuales a la hora de llevar a cabo la adopción conjunta de menores.

En efecto, para los recurrentes, la ampliación a las parejas homosexuales de la posibilidad de adoptar, de acuerdo con la Ley 13/2005, podría conculcar el deber de protección integral de los hijos derivado del art. 39.2 CE. La posición jurídica defendida por los recurrentes partía de considerar que esta previsión legal resultaba contraria al mandato constitucional de la protección integral de los hijos ya que -en su opinión- el legislador habría priorizado «la legitimación u homologación de las relaciones homosexuales al interés del menor, que también es el interés rector de la adopción, así como a la idoneidad de los adoptantes».

La cuestión se podría formular del siguiente modo: ¿en qué medida debe prevalecer el interés del menor sobre las aspiraciones y deseos de quienes quieren adoptar? Esta cuestión consecuente se proyecta directamente sobre el problema de la condición de homosexual, como elemento o causa susceptible de perjudicar el citado interés del menor protegido por el ordenamiento jurídico.

Nuevamente hemos de acudir a la jurisprudencia de la Corte de Estrasburgo que ha operado una evolución considerable en esta materia. En efecto, si inicialmente el TEDH proporciona una solución parcial a este tema en el caso Frette contra Francia, STEDH de 26 de febrero de $2002^{36}$, donde afirmaría que del CEDH no se puede deducir que ni se impide ni se permite adoptar a los homosexuales. Si bien el TEDH concreta que «La adopción es «dar una familia a un niño, y no un niño a una familia» y el Estado debe asegurarse de que las personas elegidas como adoptantes sean las que puedan ofrecerle, desde todos los puntos de vista, las condiciones más favorables». Seis años después el TEDH ha modificado sustancialmente su jurisprudencia a partir del Caso E.B. contra Francia de 22 de enero de 2008, condenando a este país por no permitir la adopción por una pareja homosexual sin hijos, al conside-

${ }^{36}$ En esta ocasión se esgrimió por el demandante ante el Tribunal de Estrasburgo que la decisión de rechazo de su solicitud de consentimiento, en el proceso de adopción, constituiría una injerencia arbitraria en su vida privada y familiar, basada tan solo en un perjuicio hacia su orientación sexual; se alegaba además que «excluir de la adopción a todo soltero homosexual basándose en el interés de cualquier menor que necesite padres adoptivos demuestra que la diferencia de trato se funda en la orientación sexual». Finalmente el TEDH, acogiéndose al margen de apreciación nacional y toda vez que «no existe un denominador común en este campo», entiende que el Estado francés ofreció una justificación objetiva y razonable y, por tanto, no se habría producido violación del art. $14 \mathrm{CEDH}$. 
rar el Tribunal de Estrasburgo que se había vulnerado el art. 14 del CEDH. Recientemente esta línea argumental se ha visto reiterada en el caso X y otros contra Austria $^{37}$, así frente al argumento esgrimido de la falta de imagen paterna que perjudicaría al menor, se obliga a derogar la ley austríaca que prohíbe adoptar hijos del cónyuge en el caso de matrimonio homosexual.

También resulta relevante para la resolución del TC el propio precedente contenido en la STC 176/2008, así como la argumentación que sustenta el fallo del TEDH en el Caso P. V. contra España, STEDH de 30 de noviembre de 2010, donde en una controversia en torno al régimen de visitas ${ }^{38}$ la Corte de Estrasburgo declaró «que lo que en modo alguno resulta constitucionalmente admisible es presumir la existencia de un riesgo de alteración efectiva de la personalidad del menor por el mero hecho de la orientación sexual de uno u otro de sus progenitores. Ello implica que la adopción de una decisión judicial consistente en suprimir, suspender o limitar el derecho de comunicación de los padres con sus hijos menores con fundamento, de forma principal o exclusiva, en la transexualidad del padre o de la madre, deba calificarse como una medida discriminatoria proscrita por el art. $14 \mathrm{CEDH».}$

Al hilo de este precedente jurisprudencial encuentra acomodo la afirmación de nuestro Alto Tribunal que pone fin al recurso de inconstitucionalidad ya que la previsión legal relativa a «cualquier otro interés legítimo que pudiera concurrir « (art. 2 LO 1/1996 de protección jurídica del menor, de modificación parcial del Código Civil y de la LEC ) no resulta conculcado por la redacción introducida en la citada Ley 13/2005, ya que -como señala el TC en la STC 198/2012- ésta garantiza que la «resolución judicial que constituya la adopción tendrá siempre en cuenta el interés del adoptando, y la idoneidad del adoptante o adoptantes para el ejercicio de la patria potestad, idoneidad que nada puede tener que ver con su orientación sexual».

Puesto que la adopción requiere resolución judicial habiendo tenido en cuenta el interés del menor y la propuesta previa de la entidad pública (art. $176 \mathrm{CC}$ ) en la que se debe contener las condiciones personales, familiares y sociales y los medios de vida del adoptante «con detalle de las razones que justifiquen la exclusión de otros interesados» (art. 1829 LEC), a priori no cabe excluir del certificado de idoneidad a las parejas homosexuales, no siendo posible la discriminación atendiendo a la identidad sexual para la resolu-

37 STEDH de 19 de febrero de 2013.

${ }^{38}$ Recuérdese que el derecho de visitas no se configura como un derecho de carácter incondicionado para los progenitores. En este sentido, el Tribunal Supremo ha señalado en una reiterada jurisprudencia que el régimen de visitas no puede ser utilizado para proteger las tensiones y la intimidad existentes entre los padres. Los órganos judiciales han de tener en cuenta «el interés genuino y prevalente del menor, ponderándolo con el de sus progenitores y sin que se advierta que tal decisión haya resultado influida (...) por un supuesto perjuicio de los órganos judiciales ante el dato de la transexualidad del padre». 
ción judicial que acuerde la adopción. Sin embargo, en relación con el interés y protección del menor, cabria preguntarse por la idoneidad y compatibilidad constitucional del establecimiento de un criterio de preferencia en favor de adoptantes heterosexuales frente a la adopción por parejas homosexuales. Dicho más claramente, cabe interrogarse sobre ¿si sería acorde con la Constitución y con la ley una decisión o criterio, adoptado por la Administración a la hora de proponer a los padres adoptivos bien por la propia autoridad judicial, a la hora de decidir sobre la adopción mediante auto, que primara a una pareja heterosexual sobre una homosexual, disponiendo ambas del correspondiente certificado de idoneidad? Es reiterada la jurisprudencia constitucional conforme a la que «el principio de igualdad en la ley no sólo exige que la diferencia de trato resulte objetivamente justificada, sino también que supere un juicio de proporcionalidad sobre la relación existente entre la medida adoptada, el resultado producido y la finalidad pretendida» (entre otras muchas STC 39/2002). Por tanto, la decisión se habría de adoptar atendiendo a la existencia de las condiciones más favorables para su desarrollo personal, ya que «el interés eminente del menor consiste, en términos jurídicos, en salvaguardar los derechos fundamentales de la persona, los derechos de su propia personalidad» (STS de 13 de mayo de 2011).

\section{ALGUNOS PROBLEMAS ESPECÍFICOS RELATIVOS A LA INVESTIGACIÓN DE LA PATERNIDAD}

La cuestión que reviste mayor interés en este ámbito no es otra que la relativa a la existencia de límites constitucionales a la investigación de la paternidad. Corresponde pues determinar el alcance y límites del reconocimiento de la investigación de la paternidad en orden a la determinación de quién puede pedirla y por qué causa. Alcanzada alguna respuesta a estas interrogantes corresponderá analizar si opera un régimen de igualdad o por el contrario de discriminación en cuanto a la determinación de la filiación matrimonial o no matrimonial.

A tenor de lo preceptuado en el art. $39 \mathrm{CE}$ «la ley posibilitará la investigación de la paternidad» en el contexto de la protección integral de los hijos, iguales éstos ante la ley con independencia de su filiación. La respuesta del legislador con la previsión de unas acciones de reclamación y de impugnación de la filiación en nuestro ordenamiento obedece al mandato de hacer posible la investigación de la paternidad. No obstante, hemos de admitir que tan sólo haremos referencia al ámbito de aplicación del Código Civil y no a lo contemplado en la legislación foral de aquellos territorios que disponen de derecho civil foral propio ${ }^{39}$.

${ }^{39}$ Ante la aparente contradicción normativa entre lo dispuesto por el Derecho civil común y el Derecho civil foral respecto a la legitimación activa para reclamar la filiación paterna de hijos no matrimoniales y la queja respecto de una presunta lesión de su derecho 
Como tuvo ocasión de afirmar el Tribunal Constitucional «en los supuestos de filiación, prevalece el interés social y de orden público que subyace en las declaraciones de paternidad, en las que están en juego los derechos de alimentos y sucesorios de los hijos, objeto de especial protección por el artículo 39.2 CE, lo que trasciende a los derechos alegados por el individuo afectado, cuando está en juego además la certeza de un procedimiento judicial» (STC 7/1994) ${ }^{40}$.

La investigación de la paternidad, tras algunas reformas legales, encuentra su regulación en el artículo 767 de la Ley de Enjuiciamiento Civil. Dicho artículo prevé que «En ningún caso se admitirá la demanda sobre determinación o impugnación de la filiación si con ella no se presenta un principio de prueba de los hechos en que se funde». En este precepto además se recoge que «la negativa injustificada a someterse a la prueba biológica de paternidad o maternidad permitirá al tribunal declarar la filiación reclamada siempre que existan otros indicios de la paternidad o maternidad y la prueba de ésta no se haya obtenido por otros medios» (art. 767.4 CC). La resolución judicial en la que se acuerde, en el curso de un pleito de filiación, un reconocimiento hematológico resultará plenamente constitucional «cuando sean consideradas indispensables por la autoridad judicial, no entrañen un grave riesgo o que-

a la igualdad y a la no discriminación por el contenido más restrictivo del derecho civil aplicable cabe recordar que el TC ya se pronunció indicando que a tenor de lo preceptuado en el art. 149.1.8 CE, «al configurar una «garantía de la foralidad civil a través de la autonomía política» de las Comunidades Autónomas donde exista un Derecho civil propio, foral o especial y atribuir a éstas la competencia para conservarlo, modificarlo y desarrollarlo, ha admitido que entre los diferentes Derechos civiles coexistentes en España pueden surgir conflictos o contradicciones normativas respecto a una misma materia, pues en el mismo precepto ha reservado al Estado la competencia exclusiva para dictar «las normas que resuelvan los conflictos de leyes»») STC 236/2000.

40 «En el fondo, no es otra cosa que asegurarle la protección que merece todo ciudadano en el reconocimiento de los derechos fundamentales del individuo como persona singular y como integrante de los grupos sociales en que se mueve, y el deber de los poderes públicos de remover todo obstáculo que se oponga al completo y armónico desarrollo de su personalidad (...)». Por ello, el interés del menor obliga a los tribunales a decidir que el niño tiene derecho a relacionarse con los miembros de su familia, con independencia de que entre ellos existan o no lazos biológicos (...) Debe concluirse que el derecho de los padres biológicos no es reconocido como principio absoluto cuando se trata de adoptar medidas de protección respecto de un menor desamparado y tampoco tiene carácter de derecho o interés preponderante, sino de fin subordinado al fin que debe atenderse de forma preferente que es el interés del menor. La adecuación al interés del menor es, así, el punto de partida y el principio en que debe fundase toda actividad que se realice en torno a la defensa y la protección de los menores. Las medidas que deben adoptarse respecto del menor son las que resulten más favorables para el desarrollo físico, intelectivo e integración social del menor y hagan posible el retorno a la familia natural, pero este retorno no será aceptable cuando no resulte compatible con las medidas más favorables al interés del menor» ( STS de 12 de mayo de 2011). 
branto para la salud de quien deba soportarlas, y su práctica resulte proporcionada, atendida la finalidad perseguida con su realización» no pudiendo ser consideradas contrarias a los derechos a la integridad física, y a la intimidad del afectado (STC 95/1999).

Ahora bien, cabe recordar que respecto de la negativa de la parte a someterse a la prueba biológica acordada, el Tribunal Constitucional ya señaló la imposibilidad de que se pudiera atribuir a dicha negativa a la práctica «un carácter absoluto de prueba de paternidad, introduciéndose una carga contra cives que no está autorizada normativamente» (STC 29/2005). En este sentido la jurisprudencia constitucional en la materia puede ser resumida en los siguientes términos «cuando las fuentes de prueba se encuentran en poder de una de las partes del litigio, la obligación constitucional de colaborar con los tribunales en el curso del proceso conlleva que dicha parte es quien debe aportar los datos requeridos, a fin de que el órgano judicial pueda descubrir la verdad» (SSTC 227/1991 y 7/1994).

La jurisprudencia del TEDH constituye un buen referente para abordar este tema del acceso de las personas a sus orígenes y a los datos identificativos de éstos, para la determinación de la verdad biológica y el conocimiento de la historia personal, no obstante se ha de tener en cuenta «el carácter confidencial de los expedientes oficiales es importante si se desea obtener informaciones objetivas y dignas de crédito; además puede resultar necesario para preservar a terceras personas», esencialmente los padres adoptivos y el padre, así como del resto de la familia biológica ${ }^{41}$.

En efecto, a través de la interpretación por el TEDH se ha reelaborado el alcance del respeto a la vida privada. Así, se ha esgrimido ante la Corte de Estrasburgo el art. 8 del CEDH para conocer la propia identidad. Como ha reiterado el TEDH «el derecho al respeto de la vida privada incluye el respeto al desarrollo de la personalidad y al desarrollo personal. En cuanto a la identidad fundamental de la persona, la cuestión del acceso a sus orígenes constituye un elemento esencial de la vida privada protegido por el art. 8 del $\mathrm{CEDH}$ ». Se establece de este modo una conexión directa entre el derecho a la identidad y la dignidad de la persona, para añadir el Tribunal que «incluso en el caso de la adopción, la posibilidad de tener acceso a sus orígenes y de poder así referir los elementos de su historia personal dependen de la liber-

${ }^{41}$ «Aunque la jurisprudencia no exige la convivencia entre los distintos miembros de la «familia», debe existir al menos relaciones personales estrechas entre ellos. La existencia de vínculos que demuestren una relación afectiva entre dos seres y su voluntad de mantener dicha relación es primordial para los órganos del Convenio. Estos últimos consideran incluso que un vínculo únicamente biológico es insuficiente, a falta de relaciones personales estrechas entre los interesados, para constituir una vida familiar en el sentido del art. 8», Caso Odièvre contra Francia, STEH de 13 de febrero de 2003. 
tad, y por tanto de la dignidad humana, esencia de los derechos garantizado por el Convenio ${ }^{42}$.

De tal modo que la invocación del art. 8 del CEDH se ha llevado a cabo respecto de la existencia de una filiación biológica entre un padre biológico y un hijo, esgrimiéndose la vulneración de este precepto ante la imposibilidad de conseguir que su paternidad biológica sea establecida; si bien ha señalado el TEDH que «sin un elemento legal o factual adicional alguno que corrobore la existencia de una relación personal íntima, no es suficiente para invocar la protección garantizada» por dicho precepto. Así, «entre los factores pertinentes susceptibles de determinar la existencia real, en la práctica, de lazos personales íntimos en estos casos, se encuentra la naturaleza de la relación entre los padres naturales y un interés demostrable y una dedicación del padre con respecto al niño, antes y después del nacimiento ${ }^{43}$. En diversas sentencias el TEDH ha tenido ocasión de pronunciarse sobre estas cuestiones relativas a la situación de las personas que tienen un interés vital, protegido por la CEDH, a recibir información necesaria para descubrir la verdad sobre un aspecto importante de su identidad personal ${ }^{44}$. También ante nuestros tribunales se han suscitado controversias sobre las mismas materias.

En nuestro ámbito geográfico más cercano existe una diversidad legislativa que puede oscilar desde el derecho de la madre a conservar en secreto su identidad en cuanto al nacimiento a tenor de la legislación francesa ${ }^{45}$, si bien atenuado en la actualidad, hasta el reconocimiento expreso del derecho a «conocer» sus orígenes como derecho fundamental de la personalidad con fundamento en la dignidad y en el libre desarrollo como declaró el Tribunal Constitucional Federal Alemán en la sentencia de 31 de enero de 1989. Igualmente la Constitución Federal Helvética reconoce tras la reforma de 1992, el

${ }^{42}$ En este sentido «el tribunal considera que el derecho a la identidad, que engloba el derecho a conocer la propia ascendencia, forma parte integrante de la vida privada (...) las personas que intentan averiguar su ascendencia tiene un interés vital, protegido por el Convenio, de obtener informaciones indispensables que le permitan descubrir la verdad sobre un aspecto importante de su identidad personal» Caso Jäggi contra Suiza, STEDH de 13 de julio de 2006. No obstante el TEDH introduce la ponderación como sucede respecto de la demanda de reconocimiento como nieta respecto de la identidad del abuelo que cede en favor de los derechos de terceros y de la seguridad jurídica, Caso Rocío Menéndez Garcia contra España, Decisión de 5 de mayo de 2009.

${ }^{43}$ Caso Krisztián Barnabás contra Hungría, STEDH de 12 de febrero de 2013.

${ }^{44}$ Caso Mikulic contra Croacia, STEDH de 7 de febrero de 2002. También en el asunto Gaskin contra Gran Bretaña, STEDH de 7 de julio de 1989, el TEDH afirmó que «las personas tienen un interés primordial protegido por el Convenio en recibir las informaciones necesarias para conocer y comprender su infancia y sus años de formación»; en el mismo sentido Caso M. G. contra el Reino Unido, STEDH de 24 de septiembre de 2002.

${ }^{45}$ Ley núm. 2002/1993 de 22 de enero relativa al acceso a los orígenes de las personas adoptadas. 
derecho a conocer sus orígenes y, en el caso de la adopción, la posibilidad de conocer el contenido de la partida de nacimiento (art. 138).

La casuística que presenta la investigación de la paternidad más allá de la negativa al sometimiento a la prueba biológica, o la posibilidad de llevar a cabo ésta en un cadáver, nos conduce al ámbito de la revelación de la identidad del donante a efectos de la determinación legal de la filiación, la impugnación de la paternidad así como la legitimación del progenitor biológico para reclamar la filiación no matrimonial.

\subsection{La revelación de la identidad del donante a efectos de la determinación legal de la filiación: un tratamiento normativo diferenciado susceptible de conculcar el principio de igualdad ante la Ley}

Aun cuando la Constitución no contiene una definición del instituto de la filiación y, por tanto, el legislador dispone de un amplio margen para su regulación, ésta queda constreñida por la obligación de la observancia del art. 14 CE y 39.2 CE. La determinación legal de la filiación regulada en la normativa civil contiene algunos preceptos que pudieran entrar en conflicto con los mandatos constitucionales como sucede con el derecho a la igualdad y la proscripción de la discriminación que debe imperar también en este ámbito. En este sentido no parece que la vigente regulación sea especialmente respetuosa con nuestra Norma Fundamental. Hemos de recordar que «la filiación puede tener lugar por naturaleza y por adopción», aunque en ambos casos «surten los mismos efectos» a tenor de lo previsto en el artículo $108 \mathrm{CC}$.

La Ley 14/2006 sobre técnicas de reproducción humana, más allá de regular la aplicación de las técnicas de reproducción humana asistida y acreditadas científicamente, en la prevención y tratamiento de enfermedades de origen genéricas, así como de los supuestos y requisitos de utilización de gametos y preembriones humanos, presenta cuestiones jurídicas de interés en el ámbito de la obtención de información relativa a los donantes por parte de los hijos nacidos de dicha reproducción asistida. En efecto, en esta norma se señala el carácter anónimo de la donación, así como la necesidad de garantía de la confidencialidad de los datos relativos a la identidad de los donantes por parte de los bancos de gametos, registros de donantes y de los centros en que se lleven a cabo dichas técnicas.

Sin embargo, el legislador ha llevado a cabo esta reserva de protección de datos relativos a la identidad hasta un límite concreto, ya que se reconoce al mismo tiempo el derecho de los hijos «por sí o por sus representantes legales a obtener información general de los donantes que no incluya su identidad».

En todo caso, la única excepción incorporada en la norma es la relativa a la concurrencia de «circunstancias extraordinarias que comporten un peligro 
cierto para la vida o la salud del hijo o cuando proceda con arreglo a las leyes procesales penales», en cuyo supuesto el legislador ha previsto que "podrá revelarse la identidad de los donantes, siempre que dicha revelación sea indispensable para evitar el peligro o para conseguir el fin legal propuesto. Dicha revelación tendrá carácter restringido y no implicará en ningún caso publicidad de la identidad de los donantes» (art. 5.5).

En contraste con esta regulación tan limitada, el Código Civil ha incorporado -en el caso de la determinación de la filiación por parte del adoptadoun tratamiento menos restrictivo, al reconocer que las personas adoptadas, una vez que han alcanzado la mayoría de edad o en su caso aun antes y con representación de sus padres, «tendrán derecho a conocer los datos sobre sus orígenes biológicos» (art. 180.5 CC).

No parece existir, por tanto, una identidad de criterio por el legislador en ambos casos, aun cuando se pueda argumentar que esta redacción del art. 180.5 CC ha sido introducida en la Ley 52/2007 de Adopción Internacional. Incluso el argumento temporal sobre ambas normas hace aún más inexplicable un tratamiento tan diferenciado y que pudiera suponer un caso de tratamiento discriminatorio de los concebidos a partir de técnicas de reproducción humana asistida frente al régimen que se aplica en estos casos a los hijos adoptados, en orden a la determinación de la filiación en uno y otro caso. No parece suficientemente justificado un tratamiento diverso por tanto para la determinación de la filiación.

\subsection{La impugnación de la paternidad (art. 136.1 CC) y la regulación de la legitimación del progenitor biológico para reclamar la filiación no matrimonial, cuando falta la posesión de estado (art. 133 CC) ${ }^{46}$}

Ambas preceptos fueron objeto de cuestiones de inconstitucionalidad planteadas por órganos jurisdiccionales y resueltas por el Tribunal Constitucional; respecto al ejercicio de la acción de impugnación de la paternidad, en la STC 138/2005 se declaró la inconstitucionalidad del párrafo primero del artículo $136^{47} \mathrm{CC}$, y en la STC 273/2005, igualmente se contiene una declaración de inconstitucionalidad del párrafo primero del artículo $133 \mathrm{CC}^{48}$.

46 «cuando existe una situación en la que, pese a no contar con una paternidad o maternidad no matrimonial reconocida formalmente, se tiene el concepto público de hijo con respecto al padre o la madre, formado por actos directos de éstos o de su familia, demostrativos de un verdadero reconocimiento voluntario, libre y espontáneo» (STS de 10 de marzo de 1988).

47 «El marido podrá ejercitar la acción de impugnación de la paternidad en el plazo de un año contado desde la inscripción de la filiación en el Registro Civil. Sin embargo, el plazo no correrá mientras el marido ignore el nacimiento».

48 «La acción de reclamación de filiación no matrimonial, cuando falte la respectiva posesión de estado, corresponde al hijo durante toda su vida». 
Nos hemos de referir en primer lugar al cuestionamiento de la adecuación constitucional de la regulación del plazo para el ejercicio de la acción de impugnación de la paternidad matrimonial. En concreto el objeto de la cuestión de inconstitucionalidad recayó en la redacción del art. 136 del CC, en virtud del cual «El marido podrá ejercitar la acción de impugnación de la paternidad en el plazo de un año contado desde la inscripción de la filiación en el Registro Civil. Sin embargo, el plazo no correrá mientras el marido ignore el nacimiento». La duda de constitucionalidad se basaba no tanto en el establecimiento de un plazo de un año de caducidad de la acción de impugnación de la paternidad matrimonial, cuanto en el hecho de que se establezca, como dies a quo para llevar a cabo el cómputo del referido plazo, la fecha de inscripción registral; sin que se haya previsto por parte del legislador la posibilidad de que, por parte del marido, se hubiera tenido conocimiento de no ser el progenitor en una fecha posterior a la inscripción registral, una vez concluido el citado plazo de caducidad de la acción.

Esta regulación podría constituir, a juicio del órgano jurisdiccional que planteó la cuestión de inconstitucionalidad, una vulneración de los artículos $39.2,24.1$ y 14 de la CE. En primer lugar porque nuestro ordenamiento establece que se debe «posibilitar la investigación de la paternidad sin obstáculos ni impedimentos». En segundo lugar, porque la regulación del ejercicio de las acciones en materia de filiación debe propiciar siempre a los interesados en la filiación el acceso a los órganos jurisdiccionales y, en tal sentido, permitir la investigación de la paternidad aunque se hayan suscitado las dudas respecto de la paternidad expirado el plazo de caducidad.

Finalmente, el órgano judicial en la cuestión de inconstitucionalidad planteada, estableció una comparación entre el apartado primero del artículo 136 y los sucesivos artículos 138 y 141 CC relativos a las impugnaciones de filiación matrimonial y no matrimonial, determinadas ambas por reconocimiento en las que haya concurrido algún vicio de consentimiento y comenzando el plazo de caducidad «desde que cesó el vicio del consentimiento»; a partir de aquí concluía que podía ser conculcado el principio de igualdad, al exigir éste que a supuestos de hecho iguales, le sean de aplicación consecuencias jurídicas diferentes sin fundamentación jurídica razonable.

En suma la inconstitucionalidad tendría su manifestación en la imposibilidad conforme a la redacción del artículo 136.1 CC de que quien es padre por presunción legal pueda ejercer la acción correspondiente desde que tenga dudas respecto de la verdad biológica de su paternidad.

Pero el Tribunal Constitucional entendió que los términos en los que se planteaba aquella comparación no eran homogéneos y por tanto resultaban inidóneos para llevar a cabo un juicio de igualdad ante la ley: «Los supuestos de hecho contemplados no presentan una igualdad sustancial y la diferenciación normativa establecida está dotada de una justificación suficiente, objetiva y razonable. Tal justificación radica en última instancia en los distintos regíme- 
nes de determinación de la filiación, y más concretamente de la paternidad. Por tanto, al fundamentarse la acción de impugnación de la paternidad matrimonial del artículo $136 \mathrm{CC}$ en presupuestos diferentes de las acciones de impugnación reguladas en los artículos 138 y $141 \mathrm{CC}$ resultaría justificada por el legislador una regulación diferente para el cómputo de los plazos de la acción de impugnación de la paternidad. En efecto, es el hecho de la existencia del matrimonio el que fija el carácter matrimonial de la filiación, determinándose legalmente la paternidad del marido de la madre a través del juego de las presunciones».

Sin embargo, el enjuiciamiento que lleva a cabo el Alto Tribunal en torno al acceso a los órganos jurisdiccionales le merece otro parecer. Es evidente que el mandato del artículo 39.2 CE está dirigido a hacer posible la investigación de la paternidad, para ello resulta decisivo garantizar el acceso a los órganos judiciales y, es aquí, donde se debe poner en relación dicho precepto con el artículo 24 $\mathrm{CE}$, toda vez que la finalidad última del artículo $136 \mathrm{CC}$ no es otra que vehicular la acción de impugnación de la paternidad matrimonial. El Tribunal Constitucional muestra su conformidad con el establecimiento de un plazo de caducidad de la acción, ya que responde a la exigencia de seguridad jurídica (art. 9.3 CE) y, por tanto, no resulta contrario al derecho a la tutela judicial efectiva «siempre que el legislador habilite unos plazos suficientes y adecuados en orden a hacer valer los derechos e intereses legítimos ante los Tribunales, de manera que su tutela no resulte imposible por insuficiencia del plazo concedido al efecto». Ahora bien, con la redacción del artículo $136 \mathrm{CC}$ resulta imposible llevar a cabo la acción de impugnación por parte del marido que ha conocido la realidad biológica, una vez que ha transcurrido el año desde que se llevó a cabo la inscripción registral. Pues bien, este impedimento de acceso a la jurisdicción por parte de quien no resulta ser progenitor biológico, una vez transcurrido más de un año de la inscripción registral de la filiación, constituye una limitación al derecho a la tutela judicial efectiva que no resulta proporcionado a la finalidad de dotar de seguridad jurídica a la filiación matrimonial.

El fallo de la STC 138/2005 declara la inconstitucionalidad del artículo 136.1 CC «en cuanto que comporta que el plazo para el ejercicio de la acción de impugnación de la paternidad matrimonial empiece a correr aunque el marido ignore no ser el progenitor biológico de quien ha sido inscrito como hijo suyo en el Registro Civil», en el mismo sentido también STC 156/2005.

Otro supuesto de relativo interés por la conexión que presenta el artículo $39 \mathrm{CE}$ con la tutela judicial efectiva es el resuelto por la STC 273/2005 que tiene su origen en una cuestión de inconstitucionalidad planteada por una Audiencia Provincial respecto del artículo 133.1 CC, al entender este órgano jurisdiccional que en los casos en los que no exista posesión de estado, el legislador habría restringido al hijo la legitimación para reclamar la filiación no matrimonial, más allá de las dudas planteadas en torno a la compatibilidad de dicha redacción con el artículo $14 \mathrm{CE}$ se aduce también que este precepto conculcaría el artículo 24 CE. Una vez tratada en la STC 138/2005 la argu- 
mentación del Alto Tribunal nos remitimos a la misma en cuanto a la no procedencia de declarar la vulneración del artículo $14 \mathrm{CE}$ por el tratamiento dado por el legislador al artículo 136.1 CC aplicable al artículo 133.1 del mismo texto ${ }^{49}$. Nos hemos de centrar, por tanto, en la consideración que tiene para el TC la regulación contenida en el artículo 133.1 CC y, en qué medida puede contravenir el derecho de acceso a los tribunales de justicia.

Como señala el Alto Tribunal para el análisis de los mecanismos que hagan posible la investigación de la paternidad y la determinación de la filiación, el legislador ha llevado a cabo en la regulación introducida en el Código Civil por la Ley 11/1981 «hacer posible el descubrimiento de la verdad biológica para que siempre pueda hacerse efectivo el derecho de los padres de prestar asistencia de todo orden a sus hijos. Pero, por otro lado, se ha procurado impedir que a voluntad de cualquier interesado puedan llevarse sin límites a los tribunales cuestiones que tan íntimamente afectan a la persona». La consecuencia que se extrae es que el legislador ha otorgado prevalencia al hijo atendiendo al mayor valor de la protección integral de los hijos y a la seguridad jurídica en el estado civil de las personas, habiendo desconocido el interés del progenitor en la declaración de la paternidad no matrimonial. Por tanto, el fallo de la STC 273/2005 señala que «la opción del legislador cercena de raíz al progenitor no matrimonial la posibilidad de acceder a la jurisdicción cuando falte la posesión de estado, impidiéndole así instar la investigación de la paternidad; esto es, en la ponderación de los valores constitucionales involucrados realizada por el legislador se ha anulado por completo uno de ellos, sin que la eliminación del derecho a la tutela judicial efectiva, en su vertiente de acceso a la jurisdicción (art. 24.1 CE), guarde la necesaria proporcionalidad con la finalidad perseguida de proteger el interés del hijo y de salvaguardar la seguridad jurídica en el estado civil de las personas».

La conclusión que se alcanza es que el superior interés del menor, como principio de obligada observancia en las relaciones paterno-filiales, no puede tener un valor absoluto que anule o impida el acceso a la jurisdicción para instar la investigación de la paternidad.

\section{LA INTROMISIÓN DEL LEGISLADOR EN ASUNTOS PERSONALÍSIMOS CONCERNIENTES AL MENOR}

Más allá del reconocimiento en abstracto de derechos del menor consagrados en nuestro ordenamiento jurídico, es cierto que se pueden suscitar

49 «lo que hace el Código Civil es establecer un sistema para la determinación, prueba, reclamación e impugnación de la filiación que se articula en función del carácter matrimonial o no matrimonial de la filiación y que, en el supuesto concreto que se nos plantea, se traduce en un diferente régimen para la reclamación de la filiación, cuando falte la posesión de estado, según sea aquélla matrimonial o no matrimonial». 
conflictos entre el ejercicio de los mismos por los menores y la facultad de disponer sobre ellos de los titulares de la patria potestad. Con carácter general el Código Civil reconoce que los padres que ostentan la patria potestad tienen la representación legal de sus hijos menores no emancipados. No obstante, el legislador ha previsto varias excepciones a dicho principio de alcance general, de un lado, los actos relativos a derechos de la personalidad u otros que a tenor de su madurez y de las previsiones legales al efecto puedan realizar por sí mismos (art. 162.1 ${ }^{50} \mathrm{CC}$ ). De otro, en los supuestos en los que se produzca un conflicto de intereses entre los titulares de la patria potestad y los menores no emancipados. Es este supuesto el que puede suscitar una mayor controversia en la práctica, ya que no resulta inverosímil una situación de clara divergencia entre padres e hijos menores no emancipados en cuestiones como la continuidad o interrupción del embarazo o la elección de un centro educativo, e incluso la mera escolarización del menor.

El legislador con carácter general ha previsto el nombramiento de un defensor del menor «siempre que el padre o la madre tengan un interés opuesto al de sus hijos no emancipados»y, cuando esta divergencia solo lo sea con uno de ellos, corresponderá al otro progenitor «representar al menor o completar su capacidad» (art. $163 \mathrm{CC})$.

\subsection{La interrupción voluntaria del embarazo de la menor de 16 y 17 años}

El espacio conflictual puede quedar abierto ante la actual regulación de la interrupción voluntaria del embarazo introducida en la Ley Orgánica 2/2010 de salud sexual y reproductiva y de la interrupción voluntaria del embarazo, en la medida en que puede surgir un conflicto de intereses entre los padres y la menor embarazada de 16 y 17 años que puede dilucidarse ante un órgano jurisdiccional.

Como recuerda el legislador en la Exposición de Motivos de la citada norma, haciéndose eco de la jurisprudencia del TEDH, «las previsiones legales deben, en primer lugar y ante todo, asegurar la claridad de la posición jurídica de la mujer embarazada y, por otro lado, que una vez que el legislador decide permitir el aborto, no debe estructurar su marco legal de modo que se limiten las posibilidades reales de obtenerlo».

Constituye el objeto de la Ley Orgánica 2/2010 garantizar los derechos fundamentales en el ámbito de la salud sexual y reproductiva, regular las condiciones de la interrupción voluntaria del embarazo y establecer las correspondientes obligaciones de los poderes públicos (art. 1). Igualmente se reconoce el derecho a la maternidad libremente decidida (art. 3.2). En con-

${ }^{50}$ Recuérdese con la excepción de los actos relativos a derechos de la personalidad u otros que a tenor de su madurez y de las previsiones legales al efecto pueda realizar por sí mismo. 
creto, «se garantiza el acceso a la interrupción voluntaria del embarazo en las condiciones que se determinan» en la Ley Orgánica. El legislador ha señalado que «estas condiciones se interpretarán en el modo más favorable para la protección y eficacia de los derechos fundamentales de la mujer que solicita la intervención, en particular, su derecho al libre desarrollo de la personalidad, a la vida, a la integridad física y moral, a la intimidad, a la libertad ideológica y a la no discriminación (art. 12).

Los requisitos necesarios para llevar a cabo la interrupción voluntaria del embarazo dentro del marco legal vigente son tres. En primer lugar, que se lleve a cabo por un médico especialista o bajo su dirección. En segundo lugar, que se practique en un centro sanitario público o privado acreditado. Por último, es preciso el consentimiento expreso y por escrito de la mujer embarazada o, en su caso, del representante legal, de conformidad con lo establecido en la Ley 41/2002, Básica Reguladora de la Autonomía del Paciente y de Derechos y Obligaciones en materia de información y documentación clínica. En efecto, esta norma dispone que «Toda actuación en el ámbito de la salud de un paciente necesita el consentimiento libre y voluntario del afectado», una vez recibida la información sobre la aplicación de procedimientos que suponen riesgos o inconvenientes de notoria y previsible repercusión negativa sobre la salud del paciente (art.8). Ahora bien, se podrá prescindir del consentimiento expreso en el supuesto de que exista «riesgo inmediato grave para la integridad física o psíquica del enfermo y no es posible conseguir su autorización, consultando, cuando las circunstancias lo permitan, a sus familiares o a las personas vinculadas de hecho a él»(art. 9.2.b).

Uno de los aspectos más novedosos que presenta Ley Orgánica 2/2010 es el relativo a las mujeres de 16 y 17 años, en la medida en que la nueva norma indica que «el consentimiento para la interrupción voluntaria del embarazo les corresponde exclusivamente a ellas de acuerdo con el régimen general aplicable a las mujeres mayores de edad». Ahora bien, al menos uno de los representantes legales, padre o madre, personas con patria potestad o tutores de ellas «deberá ser informado de la decisión de la mujer». Si bien puede prescindirse por completo del consentimiento «cuando la menor alegue fundadamente que esto le provocará un conflicto grave, manifestado en el peligro cierto de violencia intrafamiliar, desamparo» (art. 13).

Habiendo sido objeto de recurso de inconstitucionalidad diversos preceptos de esta norma hemos de recordar que también es objeto de impugnación por los recurrentes la regulación del consentimiento de la madre para llevar a cabo la interrupción voluntaria del embarazo. Especialmente cuestionado es el supuesto ya comentado que permite a las mujeres de 16 y 17 años prescindir del consentimiento de sus padres o tutores cuando pudiera producirse una situación de conflicto grave con aquéllos (art. 13.4).

Pues bien en este contexto, al menos dos escenarios teóricos pueden ser objeto de análisis, la posición contraria de los progenitores a la voluntad de 
la hija menor embarazada de 16 y 17 años así como, en el supuesto de estar ésta bajo la protección de un Centro de Menores, la divergencia entre aquél y ésta respecto de la prolongación o interrupción del embarazo.

En efecto, nos hemos de plantear la viabilidad de la acción judicial ejercitada por los padres de la menor embarazada al objeto de interesar del órgano jurisdiccional la autorización de la interrupción del embarazo de la menor. Ciertamente esta cuestión puede suscitarse en un contexto concreto: que la menor embarazada no tenga diagnosticada ni esté aquejada de enfermedad psiquiátrica; tampoco esté incapacitada judicialmente; haya mostrado su deseo de tener al hijo y no se disponga de informe médico alguno que haga aconsejable la interrupción del embarazo o que resulte concluyente respecto del carácter perjudicial para el bebé o la madre del alumbramiento.

En sentido contrario, cabe imaginar la situación en la que la menor embarazada que estando bajo tutela de la Comisión de Tutela del Menor, hubiese obtenido resolución denegatoria de la autorización presentada a ésta para la interrupción voluntaria del embarazo. La menor podría instar judicialmente la revocación de la resolución denegatoria de la Comisión de Tutela del Menor y la consiguiente autorización de la interrupción del embarazo, a través de la presentación de demanda de solicitud de interrupción de embarazo al amparo del art. 158.4 CC, toda vez que el juez a instancia del propio hijo, de cualquier pariente o del Ministerio Fiscal dictará en general «las demás disposiciones que considere oportunas a fin de apartar al menor de un peligro o de evitarle perjuicios».

El órgano judicial competente en ambos casos tendría que ponderar los intereses en juego para decidir respecto a la interrupción voluntaria del embarazo y su posible justificación, siempre que no constituyera infracción penal y concurriesen los restantes requisitos del artículo 417 bis del Código Penal.

El derecho a la maternidad libremente decidida, que implica, entre otras cosas, que las mujeres puedan tomar la decisión inicial sobre la continuidad de su embarazo o la interrupción del mismo y que esa decisión, consciente y responsable, sea respetada, puede entrar en colisión, cuando se trata de una menor de 16017 años, con la voluntad de los padres o representantes legales de la menor embarazada y, deberá ser resuelto de forma que pueda quedar salvaguardada la voluntad de la menor embarazada dentro de los términos contenidos en la Ley Orgánica 2/2010. En caso de interrupción voluntaria del embarazo, constando la oposición de sus padres, planteándose la disputa judicialmente, cabe cuestionarnos ¿en qué circunstancias podría desestimar un órgano jurisdiccional una solicitud para autorizarla, tratándose del embarazo de una menor de 16 o 17 años? ¿en qué medida consideraría atendible el derecho de la menor a su integridad física y su intimidad? Como regla general cualquier situación de conflicto debe interpretarse del modo más favorable a los derechos de la mujer aunque ésta sea una menor de 16 o 17 años. 


\subsection{La atribución de la facultad de decidir sobre la educación a recibir por el menor}

Entre los derechos que afectan de un modo directo a la esfera de la personalidad, el derecho fundamental a la educación presenta diversos perfiles susceptibles de estudio desde esta perspectiva.

Cabe recordar el carácter controvertido del derecho a la educación y su concreción en el sistema público de enseñanza. Como es notorio, el derecho fundamental a la educación es objeto de reconocimiento constitucional en el artículo $27 \mathrm{CE}$. Este derecho comprende la Enseñanza Primaria y Secundaria obligatoria, con un desarrollo desde los seis a los dieciséis años.

Como es notorio, no resulta pacifica la conciliación del ejercicio del derecho de libertad religiosa y el derecho a la educación, claro está que el conflicto entre ambos puede resultar inevitable, no obstante la aplicación del principio de proporcionalidad puede aportar alguna ayuda a su resolución atendiendo al menor daño o perjuicio que se pueda causar. Esto ocurre cuando se argumenta la correspondencia exclusiva de los padres de los alumnos de la decisión relativa a la educación de los hijos.

Para abordar este análisis también contamos con jurisprudencia del TEDH que constituye un precedente indispensable para la configuración de una doctrina constitucional sobre el alcance y contenido del derecho fundamental a la educación en el contexto de una sociedad plural y diversa en un Estado aconfesional. La existencia de sistemas públicos de enseñanza ha sido cuestionado en diversos Estados Parte del CEDH, desde la perspectiva del derecho de los padres a que sus hijos reciban una formación religiosa y moral que esté de acuerdo con sus propias convicciones -en términos de nuestra Constitución-. Según ha reconocido el TEDH «la escolarización obligatoria en el ámbito de la educación primaria no priva a los padres demandantes de su derecho a ejercer sobre sus hijos las funciones de educadores propias de su condición parental, ni a guiar a sus hijos hacia un camino que resulte conforme con sus propias convicciones religiosas o filosóficas» (Caso Kjeldsen, Busk Madsen y Pedersen contra Dinamarca, STEDH de 7 de diciembre 1976). Aunque la estrategia de acudir a la jurisprudencia del TEDH en esta materia queda lastrada por la contradicción manifiesta en que incurrió dicho Tribunal en las sentencias de Sala $^{51}$ y de Gran Sala que resolvieron el Caso Lautsi contra Italia.

${ }^{51}$ En esta primera resolución se afirma que la presencia de crucifijos en el aula se asocia a los símbolos de la iglesia católica y, por tanto resulta incompatible con el pluralismo que debe promover el Estado en el sistema público de enseñanza (STEDH de 3 de noviembre de 2009). Sin embargo el fallo definitivo pronunciado por la Gran Sala contiene la afirmación de que con el mantenimiento del crucifijo en las aulas las autoridades actuaron dentro del margen de apreciación en el marco de su obligación de respetar el derecho de los padres de garantizar esta educación conforme a sus creencias, STEDH de 18 de marzo de 2011. 
El aprendizaje y la práctica del culto de las religiones tiene un marco constitucional de referencia en la afirmación de que «los poderes públicos garantizan el derecho que asiste a los padres para que sus hijos reciban la formación religiosa y moral que esté de acuerdo con sus propias convicciones» (art. 27.3 CE). La Ley Orgánica 7/1980 de Libertad Religiosa (en adelante LOLR) especifica que la libertad religiosa y de culto comprende «recibir e impartir enseñanza e información religiosa de toda índole (...) dentro y fuera del ámbito escolar (art. 2, c) $)^{52}$. Además, la libertad religiosa incluye «elegir para sí, y para los menores no emancipados e incapacitados, bajo su dependencia» la educación religiosa y moral conforme a las creencias de los padres, cuestión esta de elevada complejidad.

Como complemento de dicho reconocimiento, la LODE en un momento inicial y con posterioridad la LOCE atribuyeron expresamente a todos los alumnos el «derecho a que se respete su libertad de conciencia, así como sus convicciones religiosas y morales (art. 6.3.e LODE). En concreto en la redacción dada por la Ley Orgánica 2/2006 a la Ley Orgánica 8/1985 se reconoce el derecho a que se respete su libertad de conciencia, sus convicciones religiosas y sus convicciones morales de acuerdo con la Constitución (ap 6.2.b, art. 6) para incidir en su apartado f) la dignidad, integridad e intimidad de todos los miembros de la comunidad educativa.

A tenor de lo preceptuado en el artículo 6 de la Ley Orgánica 1/1996 el menor es titular del «derecho a la libertad ideológica, conciencia y religión» si bien este reconocimiento debe ser acompasado con el derecho y el deber de los padres y tutores «para que el menor ejerza esta libertad de modo que contribuya a su desarrollo integral». En todo caso en este mismo texto legal se señala expresamente que «en aplicación de la presente ley primará el interés superior de los menores sobre cualquier otro interés legítimo que pudiera concurrir», sin olvidar que «las limitaciones a la capacidad de obrar de los menores se interpretarán de forma restrictiva» (art. 2). Los menores de edad son titulares plenos de sus derechos fundamentales, en concreto por lo que aquí concierne, de los derechos a la libertad de creencias y a su integridad moral. La cuestión que se suscita es por tanto la de los límites a la facultad de disponer por los menores frente a las decisiones y actuaciones que puedan decidir y realizar quienes tengan atribuida su patria potestad. Es evidente que la incidencia sobre el disfrute del menor de sus derechos fundamentales se deberá modular en función de la madurez del mismo.

Conviene recordar, en primer lugar, que el derecho de los padres a elegir un centro docente para sus hijos, la elección de una formación religiosa y moral, así como el derecho a optar entre la escuela pública y la privada cons-

${ }^{52}$ Debemos recordar que la Ley Orgánica de Protección Jurídica del Menor establece que «Los padres o tutores tienen el derecho y el deber de cooperar para que el menor ejerza esta libertad de modo que contribuya a su desarrollo integral» (art. 6.3). 
tituyen premisas previas que pueden incidir finalmente en la determinación del alcance de la facultad del titular de la patria potestad sobre el menor en su escolarización en un centro público, privado o concertado con un ideario determinado.

Sin embargo, hay que precisar el alcance de la libertad de creencias en el caso del menor, ya que con particular incidencia en el derecho de los padres a elegir la formación moral de los hijos respecto de la libertad religiosa, el TC ha señalado que «desde la perspectiva del art. $16 \mathrm{CE}$ los menores de edad son titulares plenos de sus derechos fundamentales, en este caso, de sus derechos a la libertad de creencias y a su integridad moral, sin que el ejercicio de los mismos y la facultad de disponer sobre ellos se abandonen por entero a lo que al respecto puedan decidir aquellos que tengan atribuida su guarda y custodia». Por tanto, también surgen perfiles polémicos en el alcance de la libertad religiosa, como sucede según nuestro Alto Tribunal con «la libertad de creencias de sus progenitores y su derecho a hacer proselitismo de las mismas con sus hijos, se alza como límite, además de la intangibilidad de la integridad moral de estos últimos, aquella misma libertad de creencias que asiste a los menores de edad, manifestada en su derecho a no compartir las convicciones de sus padres o a no sufrir sus actos de proselitismo, o más sencillamente, a mantener creencias diversas a las de sus padres, máxime cuando las de éstos pudieran afectar negativamente a su desarrollo personal». Libertades y derechos de unos y otros que, de surgir el conflicto, deberán ser ponderados teniendo siempre presente el «interés superior de los menores de edad» (STC 144/2000).

Por tanto, en caso de divergencia entre los progenitores y los menores en relación a las creencias de éstos cabe preguntarse si $i s e$ puede atribuir por los órganos jurisdiccionales a los titulares de la patria potestad la facultad de decidir sobre la educación religiosa a recibir por los hijos comunes menores de edad? Además, en caso de discrepancia entre ellos, ¿se puede llevar a cabo la atribución en exclusiva a uno de los progenitores de la facultad de decidir sobre dicha educación?

En todo caso y de forma colateral dentro del ámbito de los derechos educativos, se ha planteado ante la jurisdicción ordinaria y, de forma subsiguiente, ante la jurisdicción constitucional en recurso de amparo la cuestión relativa a la objeción a la escolarización obligatoria (homeschooling). El punto de partida en este conflicto es el del controvertido entendimiento del alcance de la obligación de escolarización conforme al artículo 154 CC como obligación derivada de la patria potestad frente a la escolarización obligatoria. Hemos de recordar de conformidad con la jurisprudencia constitucional que el artículo 27.4 CE no permite que los padres nieguen a los hijos el derecho y la obligación que tienen de participar en el sistema oficial de educación. En efecto, el artículo 27.3 CE no ampara el derecho de los padres a la no escolarización de los hijos bajo el pretexto de que sólo ellos sabrán impartir la educación ade- 
cuada (STC 133/2010). Como ya señalara nuestro Alto Tribunal «el derecho a ser escolarizado es un derecho del menor, no de los padres, que convive con la consiguiente obligación de los poderes públicos de procurar dicha escolarización, incluso imperativamente si ello fuera necesario $\rangle^{53}$. Constituye pues el elemento central de discusión la perspectiva constitucional de la obligatoriedad de la enseñanza básica (art. 27.4 CE) y, por tanto, esta es la cuestión a dirimir para la resolución del recurso de amparo aquí comentado. Pues bien, frente al alegado derecho de los progenitores, el TC ha afirmado que «Ningún padre puede negar a sus hijos el derecho y el deber de participar en el sistema oficial de educación, que deriva del mandato constitucional de la enseñanza obligatoria (art. 27.4 CE) y, de otra parte, que la escolarización obligatoria está integrada en el contenido mismo del derecho a la educación» (STC 133/2010).

La conclusión alcanzada por el TC es que la conducta de los padres consistente en no escolarizar a sus hijos, «supone el incumplimiento de un deber legal -integrado, además, en la patria potestad-que resulta en sí misma antijurídica» (STC 133/2010).

Continuado con el derecho de todos a la educación y la facultad de los padres de elegir el centro docente de sus hijos, es necesario precisar que el derecho de los padres para escolarizar a su hijo en un centro educativo y no en un centro de educación especial no está incluido en ese derecho. Recientemente el Tribunal Constitucional ha tenido ocasión de pronunciarse sobre el carácter inclusivo del sistema educativo y los centros de educación especial. En esta ocasión se había advertido desde el centro educativo público las dificultades de adaptación y de aprendizaje del pequeño (audición y lenguaje), con informe de la inspección favorable al cambio de centro por presentar necesidades educativas especiales y su escolarización en un centro de educación especial ${ }^{54}$. Es cierto que en favor del proceder de la administración educativa se ha acreditado que por ésta se habían llevado a cabo sucesivas evaluaciones de dicho alumno, que habían evidenciado las dificultades de adaptación como de aprendizaje y las carencias al presentar necesidades educativas especiales. A la vista de estos antecedentes la administración educativa acordó contra la voluntad expresada en reiteradas ocasiones por los padres, la escolarización de oficio en un Centro de Educación Especial.

53 Voto particular Magistrado Vicente Gimeno Sendra STC 260/1994. Concluye este Magistrado que «la libertad religiosa no ampara un supuesto derecho de los padres a la no escolarización de los hijos bajo el pretexto de que sólo ellos han de impartir la educación que estimen conveniente».

${ }^{54}$ Ley orgánica 2/2006, de 3 de mayo de educación en orden a la escolarización de los alumnos que presenten necesidades educativas especiales que su escolarización se llevara a cabo en centros de educación especial »cuando sus necesidades no puedan ser atendidas en el marco de las medidas de atención a la diversidad de los centros ordinarios» (art. 74.1). 
Los familiares del menor recurren la decisión de la administración educativa por entender que la escolarización del menor en un centro de educación especial fomenta un trato discriminatorio por su discapacidad y es perjudicial para su formación, en la medida en que supone una segregación y se opone a la educación inclusiva, al objeto de que el derecho a la educación tenga lugar en el sistema educativo ordinario con las adaptaciones que resulten precisas. Agotada la vía judicial previa, se plantea recurso de amparo con fundamento en el carácter inclusivo de la escolarización de las personas discapacitadas, invocándose la vulneración del derecho a la educación (art. 27) a la igualdad (art. 14) así como a la Convención Internacional sobre los derechos de las personas con discapacidad aprobada por la Organización de Naciones Unidas el 13 de diciembre de 2006. Asimismo se invoca el vacío en el que queda el reconocimiento del derecho a la educación en igualdad como consecuencia de la interpretación realizada por la administración educativa dentro de su discrecionalidad.

Para el Alto Tribunal el derecho de todos a la educación «no incluye, como parte o elemento del derecho constitucionalmente garantizado, el derecho de los padres a escolarizar a su hijo en un centro ordinario de educación, en lugar de hacerlo en un centro de educación especial, pues ello vendrá condicionado a la acreditación por parte de las autoridades competentes de las necesidades educativas específicas del menor». El parecer del Tribunal se concreta en la denegación de amparo interesada por los padres del menor por entender que en este caso concreto y a tenor de lo preceptuado en el artículo 74.1, las necesidades del alumno no pueden ser atendidas en el marco de las medidas de atención a la diversidad de los centros ordinarios ${ }^{55}$.

La sentencia cuenta con un voto particular en el que el Magistrado que lo suscribe se alinea con el Ministerio Fiscal en la necesidad de que por parte de la administración se motive y pondere la decisión, concluyéndose que ni por parte de la administración se ha «explicitado por qué los ajustes que debía realizar para proporcionar el menor la educación inclusiva a la que, en principio tiene derecho, no son razonables o suponen una carga desproporcionada o no serían suficientes para la inclusión el menor» (STC 10/2014).

TITLE: Equality in the constitutional regulation of family, marriage and minor children.

RESUMEN: la observancia del principio de igualdad de las personas ante la ley en el ámbito de los diferentes tipos de uniones familiares así como

55 «en interés del menor resulta indicada su escolarización en un centro de educación especial, (...) sus singulares necesidades educativas estén mejor atendidas en un centro de educación especial más que en el marco de la educación general de los centros ordinarios». 
entre los integrantes de las mismas. La observancia de la igualdad entre los cónyuges así como de los miembros de las uniones de hecho y la ausencia de discriminación por el tratamiento diferenciado en la ley de las consecuencias jurídicas para los cónyuges como para los convivientes, especialmente cuando se produce la crisis y ruptura de ambas. La prevalencia del interés superior del menor en las relaciones paterno filiales en contextos concretos: investigación de la paternidad, interrupción del embarazo, elección de la formación educativa.

PALABRAS CLAVE: principio de igualdad, uniones de hecho, matrimonio

ABSTRACT: Observance of the principle of equality of individuals before the law in the field of different models of family unions and among the members thereof. The observance of equality between spouses as well as members of civil unions and the absence of differential treatment discrimination in the law of the legal consequences for spouses and for partner cohabitants, especially when crisis or rupture comes in both cases. The prevalence of the interest of the child in parent-child relations in specific context: investigation of paternity, pregnancy termination, choice of religious education.

KEY WORDS: principle of equality, partnerships, marriage 